\title{
Green spaces, especially forest, linked to lower SARS-CoV-2 infection rates: A one-year nationwide study
}

Bin Jiang ${ }^{\text {a, }}$, Yuwen Yang ${ }^{\text {a, }}$, Long Chen ${ }^{c}$, Xueming Liu ${ }^{\text {a, }}{ }^{\text {, }}$, Xueying Wu ${ }^{c}$, Bin Chen ${ }^{b}$, Chris Webster $^{\mathrm{d}}$, William C. Sullivan ${ }^{\mathrm{e}, \mathrm{f}}$, JingJing Wang ${ }^{\mathrm{c}, \mathrm{g}}, \mathrm{Yi} \mathrm{Lu}^{\mathrm{c} *}$

${ }^{a}$ Virtual Reality Lab of Urban Environments and Human Health, HKUrbanLabs, Faculty of Architecture, The University of Hong Kong, Hong Kong Special Administrative Region

bivision of Landscape Architecture, Department of Architecture, The University of Hong Kong, Hong Kong Special Administrative Region

${ }^{\mathrm{c}}$ Department of Architecture and Civil Engineering, College of Engineering, City University of Hong Kong, Hong Kong Special Administrative Region

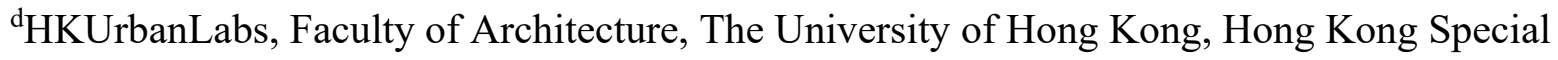
Administrative Region

${ }^{\text {e}}$ Smart, Healthy Communities Initiative, University of Illinois at Urbana-Champaign, USA

fDepartment of Landscape Architecture, University of Illinois at Urbana-Champaign, USA

gSchool of Urban Design, Wuhan University, Wuhan, China

*Corresponding author: Department of Architecture and Civil Engineering, College of Engineering, City University of Hong Kong, Hong Kong. Email: yilu24@cityu.edu.hk 


\begin{abstract}
:
This study examined the associations between green spaces and one-years' worth of SARS-CoV2 infection rates across all 3,108 counties in the contiguous United States after controlling for multiple categories of confounding factors. We found green spaces at the county level have a significant negative association with infection rates. Among all types of green spaces, forest yields the most consistent and strongest negative association. Sensitivity analyses confirmed the negative association of forest across five urbanicity levels, and the strength of the association increases as disease incidence increases across five time periods. Although forest located in moderately urbanized counties yields the strongest association, the negative pattern of significant associations holds across all five urbanicity levels. A population-weighted analysis revealed that proximity to forest within a moderate walking distance $(\leq 1.0-1.4 \mathrm{~km})$ may provide the greatest protection against the risk of infection.
\end{abstract}

\title{
Keywords:
}

COVID-19; contact with nature; spatiotemporal relationship; walking distance; optimal effect 
medRxiv preprint doi: https://doi.org/10.1101/2021.08.04.21261420; this version posted August 8, 2021. The copyright holder for this preprint (which was not certified by peer review) is the author/funder, who has granted medRxiv a license to display the preprint in perpetuity.

All rights reserved. No reuse allowed without permission.

\section{Introduction}

The coronavirus disease 2019 (COVID-19) pandemic is an ongoing global crisis that has profoundly affected people's health and wellbeing across the world (Holman et al., 2020; Walker et al., 2020; World Health Organization, 2021). A variety of studies have investigated the risk of infection with Severe Acute Respiratory Syndrome Coronavirus 2 (SARS-CoV-2), which causes COVID-19, from medical, social, economic, demographic, and architectural perspectives (Badr et al., 2020; Carteni et al., 2020; Mena et al., 2021; Muller et al., 2021). There is growing evidence that we have overlooked the salutary impact that nearby green spaces may have for lowering the risk of infection with SARS-CoV-2. The cost of this oversight is that we continue to create and manage built landscapes that increase the risk of infection to SARS-CoV-2 today, and that we fail to learn the extent to which land use patterns might alleviate the spread of this and other airborne infectious diseases.

Two recent studies suggest that green spaces may provide some protection against infection with SARS-CoV-2 (Lu, Chen, et al., 2021; Klompmaker, et al., 2021). The data employed in one of these studies was limited to the first wave of infections in the US that occurred from January to June, 2020 and in the other study from March to June, 2020.

Did the initially reported negative relationship found in these first two studies between green space and infection rates hold over the much larger second and third waves of the pandemic? What new can we learn about the characteristics of the green settings, population density, and the optimal buffer distance of green space exposure for reducing SARS-CoV-2 infection rates?

We consider these questions below. We begin with a review theory and published studies regarding the salutary effects that grow from exposure to green spaces and identify the gaps in our knowledge 
medRxiv preprint doi: https://doi.org/10.1101/2021.08.04.21261420; this version posted August 8, 2021. The copyright holder for this preprint (which was not certified by peer review) is the author/funder, who has granted medRxiv a license to display the preprint in perpetuity.

All rights reserved. No reuse allowed without permission.

that exist after the publication of the two previous studies regarding green spaces and SARS-CoV2. Next, we report findings from a new study designed to overcome the weakness for the previous studies and end by considering the implications of the findings for policies, regulations, and planning and design interventions that might alleviate current and future airborne pandemics.

\subsection{Accumulating evidence: The health benefits of green spaces}

The relationship between green spaces and public health is a rapidly growing field of research. In recent decades, several studies have reported on the multiple health benefits of green space exposure. The relationship between green space exposure and health outcomes has been measured at national (e.g., Lu, Chen, et al., 2021; Mitchell \& Popham, 2008; Nowak et al., 2014), city (e.g., Donovan et al., 2011; Melis et al., 2015), and community/site (e.g., Chang et al., 2021; Kuo \& Sullivan, 2001) scales. Green spaces, especially those in close proximity, can affect three main categories of health outcomes: mental (Jiang et al., 2014; Jiang et al., 2018), physical (Jiang, Larsen, et al., 2020; Lu, 2018; Mitchell \& Popham, 2008), and social (Helbich et al., 2020; Holtan et al., 2014). The effects of green spaces on such health outcomes are complex and interdependent (Jiang, Zhang, et al., 2015; Sullivan \& Bartlett, 2005). For example, green spaces can significantly reduce mental stress and fatigue, which positively influences immune function and promotes physical health (Kuo, 2015; Li et al., 2010; Parsons et al., 1998). Exposure to green spaces can also promote social cohesion and can improve physical activity levels and perceived safety. Green spaces, especially forest, can decrease air pollutants, provide pleasant visual and acoustic experiences, and create a comfortable microclimate. These critical ecological functions encourage outdoor physical activities, further enhancing mental and social health (Nowak et al., 2014; Ouyang et al., 2020; Power et al., 2015). Overall, it is widely recognized that green spaces, whether in urban or rural areas, have a significant positive effect on human health. 
medRxiv preprint doi: https://doi.org/10.1101/2021.08.04.21261420; this version posted August 8, 2021. The copyright holder for this preprint (which was not certified by peer review) is the author/funder, who has granted medRxiv a license to display the preprint in perpetuity.

All rights reserved. No reuse allowed without permission.

\subsection{A critical knowledge gap: The relationship between green spaces and SARS-CoV-2 infection rates}

The published research leaves us with a critical knowledge gap in our understanding: we do not know the extent to which exposure to green settings, especially forest, reduce SARS-CoV-2 infection risk. Two studies have attempted to investigate this relationship, however the findings were inconclusive. One study examined the 135 most urbanized counties in the contiguous United States, and found that a higher ratio of green spaces was significantly associated with a lower racial disparity in SARS-CoV-2 infection rates at the county level (Lu, Chen, et al., 2021). However, this study did not determine the association between the supply of green spaces and the general population's infection rate across all counties in U.S., which have varying levels of urbanicity and population densities. Additionally, the infection data used in the study spanned a relatively short time period (from January to June, 2020), and excluded the moderate and peak periods of infection (from August to December, 2020).

The second study examined the association between county-level green vegetation measured by the normalized difference vegetation index (NDVI), and SARS-CoV-2 infection and death rates for 2,297 counties in the United States (Klompmaker et al., 2021). That study reported "greenness" was negatively associated with county-level SARS-CoV-2 infection rates. This study, however, had three important limitations. First, it did not identify the types of green spaces that were associated with lower infection rates. Second, the study period was relatively short (from March to June, 2020). Third, some important confounding factors were not controlled, including transportation infrastructure and services (Carteni et al., 2020; Tirachini \& Cats, 2020), political and administration factors (Clinton et al., 2021), human mobility (Muller et al., 2021), commuting mode (Figueroa et al., 2021), and employment status (Mena et al., 2021). 
medRxiv preprint doi: https://doi.org/10.1101/2021.08.04.21261420; this version posted August 8, 2021. The copyright holder for this preprint (which was not certified by peer review) is the author/funder, who has granted medRxiv a license to display the preprint in perpetuity.

All rights reserved. No reuse allowed without permission.

The promise and weaknesses associated with these two previous studies demonstrate the necessity and urgency of conducting a more comprehensive assessment regarding the relationship between green spaces and SARS-CoV-2 infection rates. Understanding this relationship will enable planners and designers to develop appropriate environmental interventions to alleviate the COVID-19 pandemic, and will shed light on how we might employ the built environment to address future pandemics.

\subsection{Research questions}

In this study, we ask five related questions to uncover the relationship between green spaces and SARS-CoV-2 infection risk:

1) What is the overall association between the ratio of green spaces within a county and SARS-CoV-2 infection rate?

2) What is the relationship between different types of green spaces and SARS-CoV-2 infection rates?

3) What is the relationship between green spaces and SARS-CoV-2 infection rates across various levels of urbanicity and over distinct time-periods during the COVID-19?

4) What is the optimal buffer distance of green space exposure associated with reduced levels of SARS-CoV-2 infection rates?

5) What mechanisms might explain these relationships? 


\section{Methods}

\subsection{Overview}

We investigated the association between the ratio of green spaces and SARS-CoV-2 infection rates in 3,108 counties in the contiguous United States from January 22 to December 31, 2020. We also examined the association between a variety of types of green space and infection rates in counties at five levels of urbanicity over five different time-periods. The effect of forest was determined for all 25 urbanicity-time-period combinations. Finally, in order to identify the optimal forest-buffer distance, we examined the relationship between forest located at different distances from human settlements and the infection rates within those settlements.

\subsubsection{Study area}

We used counties, which are fundamental administrative boundaries of the United States, as the basic units of analysis, as infection data were most complete at the county level. Accordingly, 3,108 counties in the contiguous United States were included.

\subsubsection{SARS-CoV-2 infection rates}

We collected the cumulative total number of positive cases of SARS-CoV-2 infection from the Centers for Disease Control and Prevention (CDC) and state- and local-level public health agencies (USAFACTS, 2021). The research period was from January 22 to December 31, 2020; we chose December 31 as the end point as the COVID-19 pandemic had reached its peak on approximately this week, despite some fluctuations (Fig. 1). Moreover, this end point fell prior to the rollout of large-scale vaccination programs and the presidential election, allowing us to avoid a more complex situation. The research period was further subdivided into five equal-length periods to 
medRxiv preprint doi: https://doi.org/10.1101/2021.08.04.21261420; this version posted August 8, 2021. The copyright holder for this preprint (which was not certified by peer review) is the author/funder, who has granted medRxiv a license to display the preprint in perpetuity. All rights reserved. No reuse allowed without permission.

investigate the temporal association between SARS-CoV-2 infection and green spaces. The five periods were from January 22 to March 30, March 31 to June 7, June 8 to August 15, August 16 to October 23, October 24 to December 31, 2020 (Fig. 1). 
medRxiv preprint doi: https://doi.org/10.1101/2021.08.04.21261420; this version posted August 8, 2021. The copyright holder for this preprint (which was not certified by peer review) is the author/funder, who has granted medRxiv a license to display the preprint in perpetuity. All rights reserved. No reuse allowed without permission.
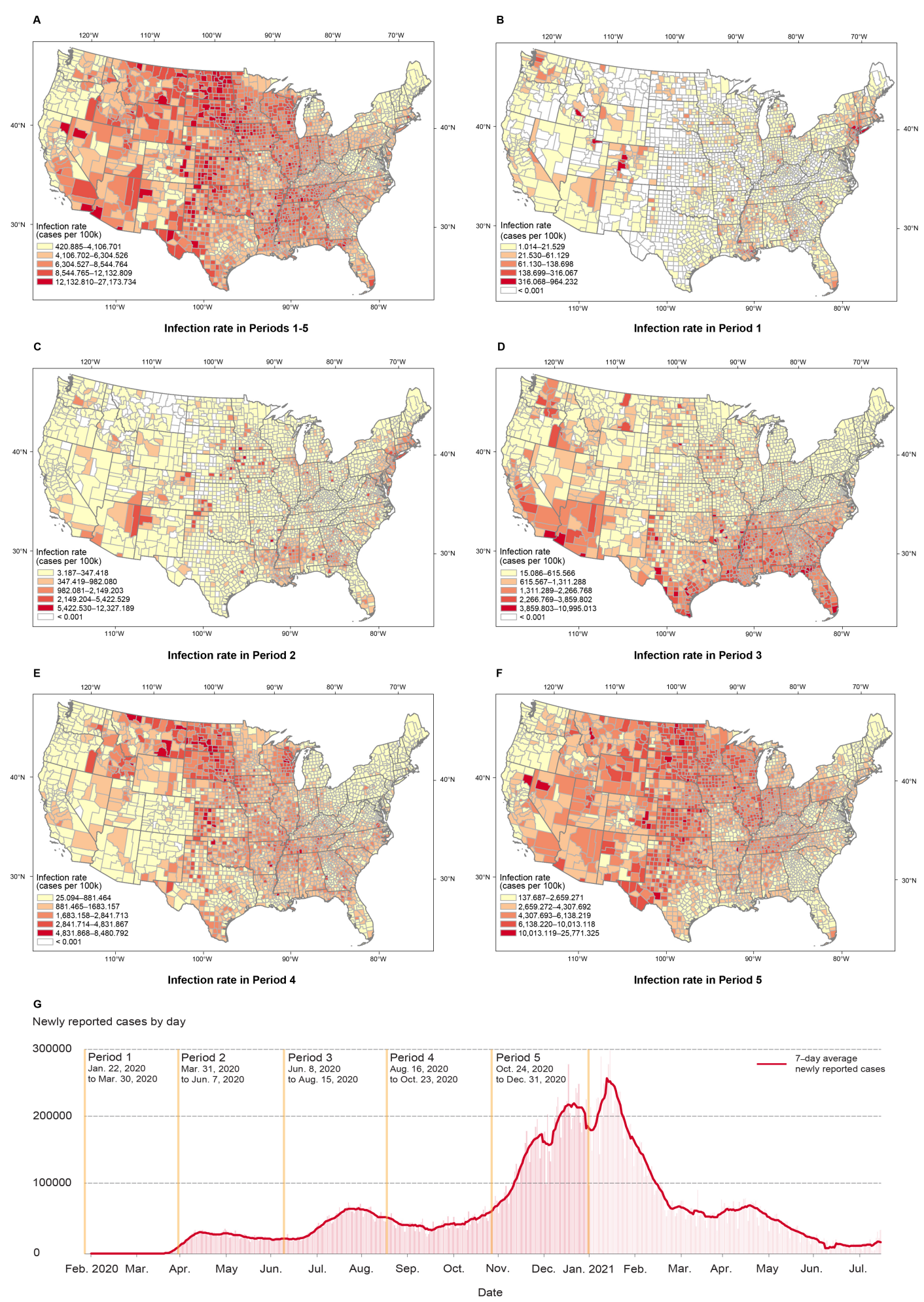

Fig. 1. County-level severe acute respiratory syndrome coronavirus 2 (SARS-CoV-2) infection rates (cases per 100,000) in total and across the five subperiods. (A) The overall research period, from January 22 to December 31, 2020. (B) Period 1: January 22 to March 30, 2020. (C) Period 2: March 31 to June 7, 2020. (D) Period 3: June 8 to August 15, 2020. (E) Period 4: August 16 to October 23, 2020. (F) Period 5: October 24 to December 31, 2020. (G) Diagram of cases of SARS-CoV-2 from February 2020 to July 2021 in the United States (The New York Times, 2021). The COVID-19 pandemic emerged in 2020 and comprised several different periods, with low, moderate, and high infection rates. The infection rate in 2021 was significantly attenuated wide-scale vaccination, so this data was not included. 
medRxiv preprint doi: https://doi.org/10.1101/2021.08.04.21261420; this version posted August 8, 2021. The copyright holder for this preprint (which was not certified by peer review) is the author/funder, who has granted medRxiv a license to display the preprint in perpetuity.

All rights reserved. No reuse allowed without permission.

\subsubsection{Green spaces}

We quantified four types of green space factors to reduce bias: land cover, local parks, tree canopies, and general greenness levels (Fig. 2 and Supplementary Table S1).

(1) Six types of land cover with predominant natural elements were assessed at a 30-m resolution based on the National Land Cover Datasets (NLCD) (MRLC consortium, 2019): Developed open space, forest, shrub/scrub, grassland/herbaceous, hay/pasture, and cultivated crops (Fig. 3 and Table S1). The ratio of each type of land cover was calculated as the area of the land cover within the county divided by the total county land area. We also calculated population-weighted forest exposure for varying buffer distances in each county to identify an optimal distance from forest, a factor that may be critical for determining the infection rate. The population-weighted exposure incorporates population spatial distributions into green space exposure estimates by giving a proportionally greater weight to green spaces near areas of higher population density. Populationweighted forest exposure was calculated in Google Earth Engine (GEE) using the NLCD 2016. Residential population densities were estimated at a $100-\mathrm{m}$ resolution for the contiguous United States using WorldPop Global Project Population Data from 2020 (Sorichetta et al., 2015). The original 30-m NLCD-based forest map was aggregated at a 100-m resolution to match that of the population data within $5 \mathrm{~km}$, whereas a spatial resolution of $1 \mathrm{~km}$ was used for distances greater than $5 \mathrm{~km}$. The population-weighted forest exposure for different buffer sizes in each county was defined by Equation 1 (Chen, Song, Jiang, et al., 2018; Chen, Song, Kwan, et al., 2018),

$$
F E=\frac{\sum_{i=1}^{N} P_{i} \times F_{i}^{b}}{\sum_{i=1}^{N} P_{i}}(\text { Equation } 1)
$$

where $P_{i}$ represents the population of the $i^{\text {th }}$ grid, $F_{i}^{b}$ represents the forest cover of the $i^{\text {th }}$ grid at a buffer size of $b$ meters, $N$ denotes the total number of grids for a given county, and $F E$ is the 
medRxiv preprint doi: https://doi.org/10.1101/2021.08.04.21261420; this version posted August 8, 2021. The copyright holder for this preprint (which was not certified by peer review) is the author/funder, who has granted medRxiv a license to display the preprint in perpetuity.

All rights reserved. No reuse allowed without permission.

estimated forest exposure level for the given county. We calculated forest exposure levels by varying the buffer size from $100 \mathrm{~m}$ to $50 \mathrm{~km}$, to examine the association between different proximities to forest and the infection rate.

(2) The data of local park were derived from the United States Parks dataset (Esri, 2021), which provides local-level details of parks and forest within the United States. The ratio of local park area was measured as the gross land area of local parks within a county divided by the total county area.

(3) The percentage of tree canopy cover was estimated from the 30-m raster dataset generated by the United States Forest Service (USFS) from satellite imagery (Coulston et al., 2013; Coulston et al., 2012).

(4) The overall greenness level for each county was assessed using Normalized Difference Vegetation Index (NDVI) values and GEE to integrate satellite imagery at a 30-m resolution (MRLC consortium, 2019). We used the mean NDVI value in 2020 as a proxy for overall green space exposure during the research period. 
medRxiv preprint doi: https://doi.org/10.1101/2021.08.04.21261420; this version posted August 8, 2021. The copyright holder for this preprint (which was not certified by peer review) is the author/funder, who has granted medRxiv a license to display the preprint in perpetuity. All rights reserved. No reuse allowed without permission.

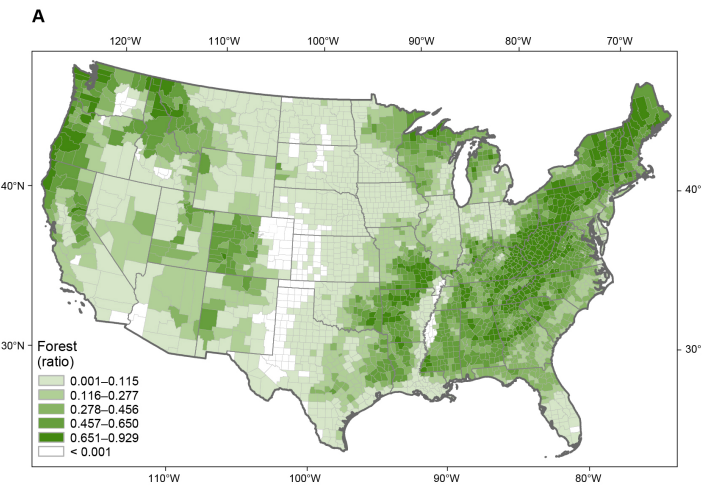$$
\text { C }
$$

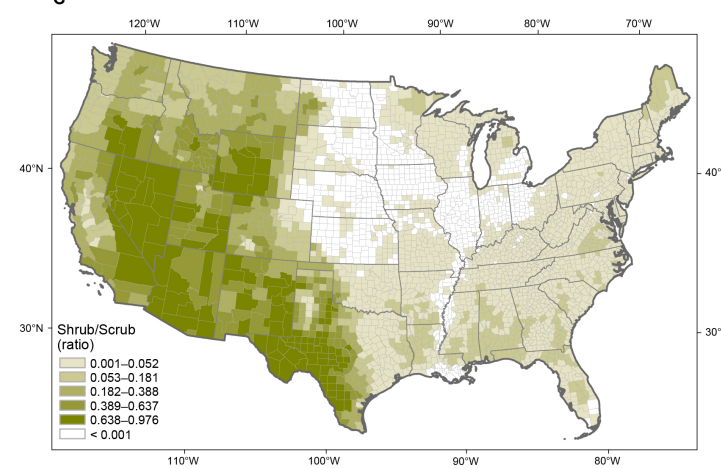

E

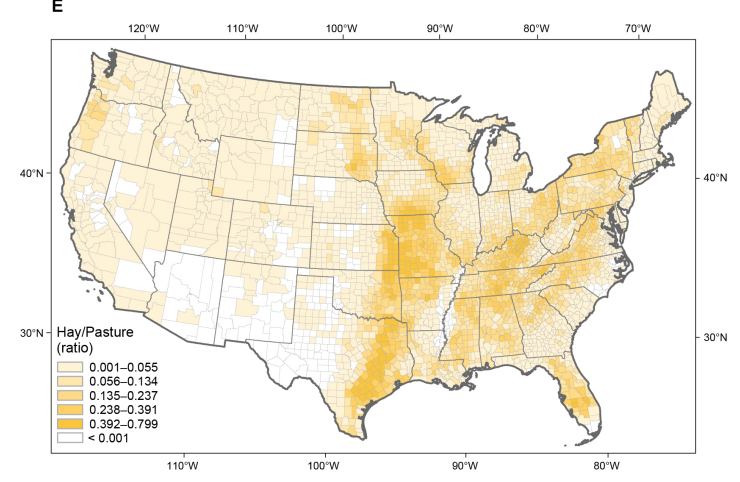

G

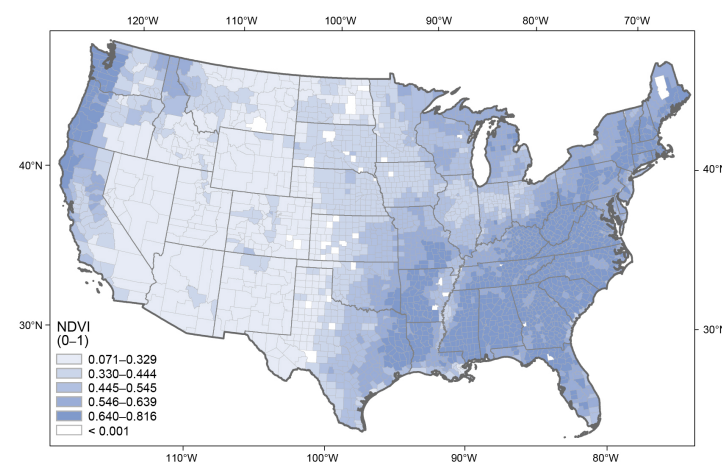

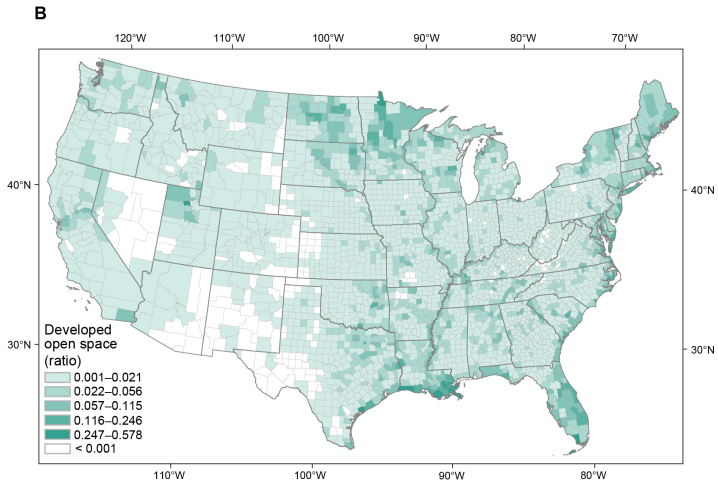

D
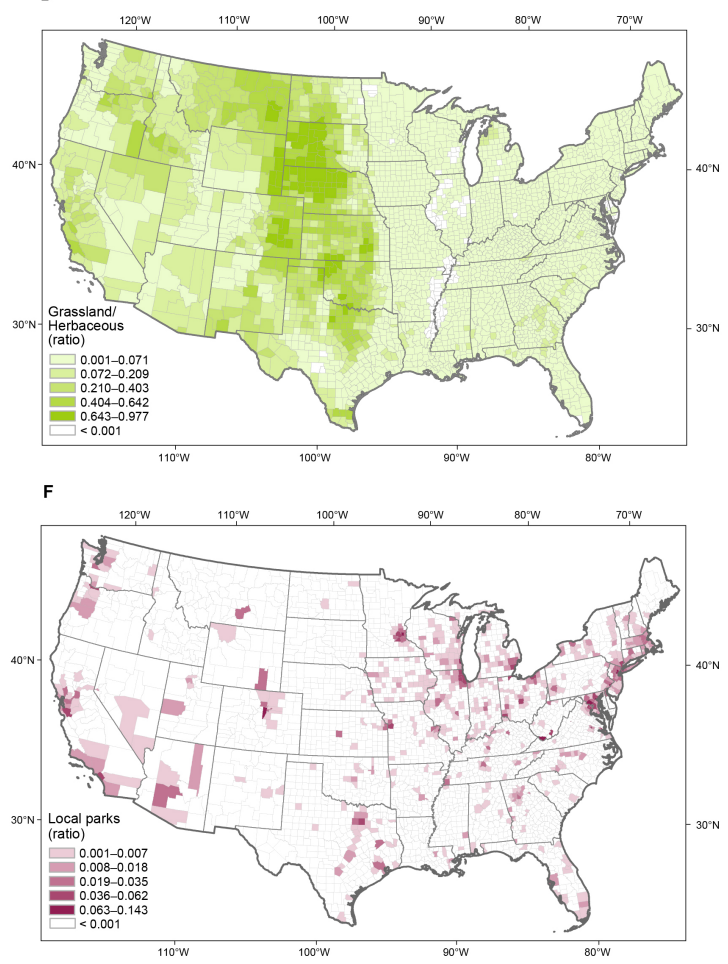

H

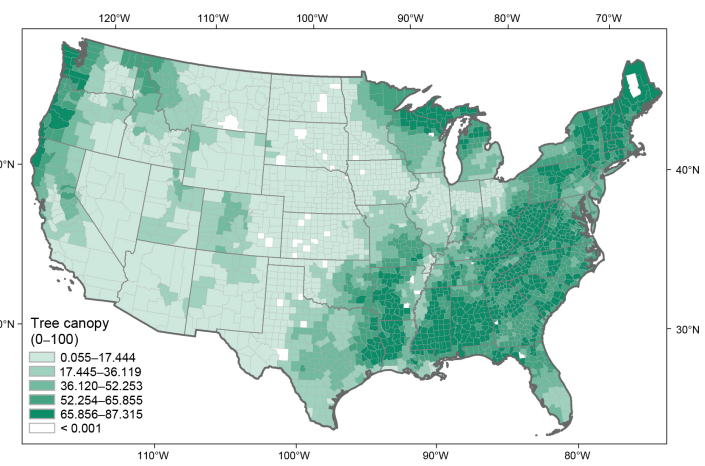

Fig. 2. Ratio of different types of green spaces at a county level. Values represent the (A) forest, (B) developed open space, (C) shrub/scrub, (D) grassland/herbaceous, (E) hay/pasture, and (F) local parks land coverage ratios at the county level, calculated as the total relevant area divided by the entire county area. Data were extracted from the NLCD landcover dataset. Local parks land coverage was calculated based on the US Parks dataset of Esri; (G) NDVI were calculated by Google Earth Engine. (H) Tree canopy data were extracted from the NLCD landcover dataset. 
medRxiv preprint doi: https://doi.org/10.1101/2021.08.04.21261420; this version posted August 8, 2021. The copyright holder for this preprint (which was not certified by peer review) is the author/funder, who has granted medRxiv a license to display the preprint in perpetuity.

All rights reserved. No reuse allowed without permission.

A
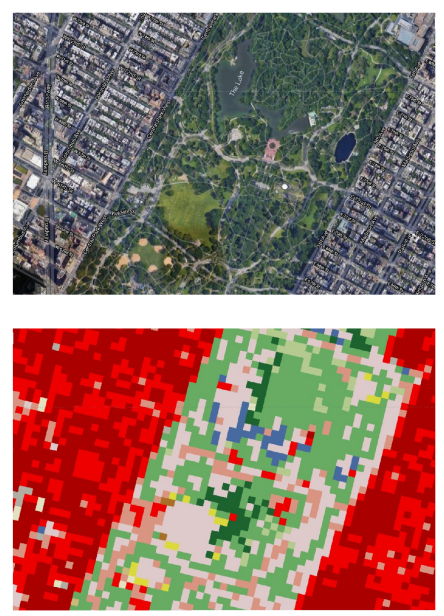

B
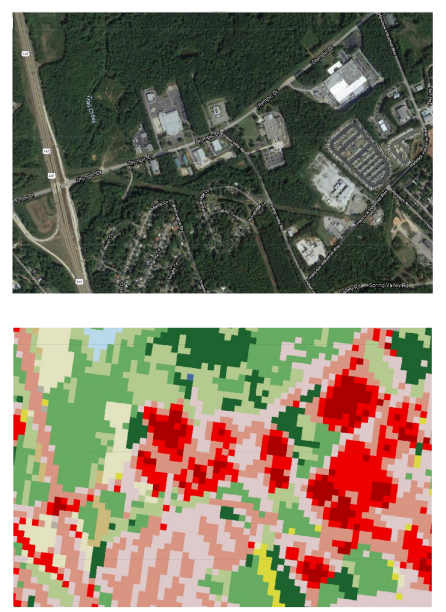

C
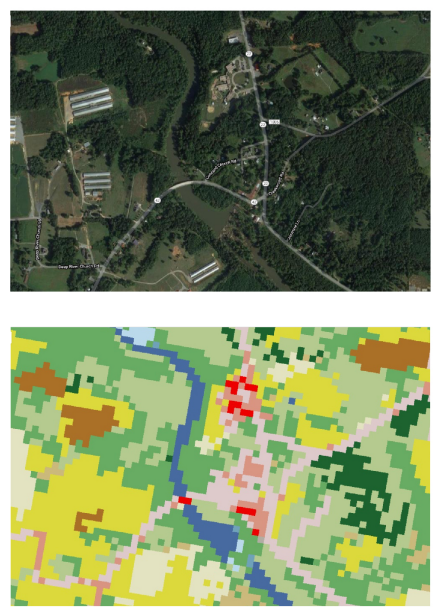

NLCD Land Cover Classification Legend

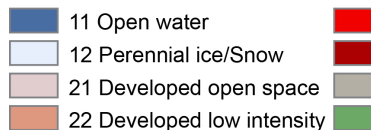

23 Developed medium intensity
24 Developed high intensity
31 Barren land
41 Deciduous forest 42 Evergreen forest 43 Mixed forest 52 Shrub/Scrub

71 Grassland/Herbaceous

81 Hay/Pasture 82 Cultivated crops 90 Woody wetlands 95 Emergent herbaceous wetlands

Fig. 3. Example of land cover distributions at three different urbanicity levels. (A) New York City, NY, urbanicity level 1; (B) Athens, GA, urbanicity level 3; (C) Coleridge, NC, urbanicity level 5. Squares marked by light, moderate, and dark green colors have been identified by NLCD as forest areas, including deciduous, evergreen, and mixed forest.

\subsubsection{Levels of Urbanicity}

Previous studies have identified an urban-rural disparity in the prevalence of SARS-CoV-2 infection in the United States (Huang et al., 2021; Pro et al., 2020). Therefore, we classified all counties into five levels of urbanicity based on the 2013 Urban-Rural Classification Scheme (NCHS, 2017), with level 1 being the most urbanized and level 5 being the most rural (Fig. S1 and Table S2).

\subsubsection{Confounding factors}

Additionally, we adjusted for potential confounding factors in each county, including healthcare and testing rates (Wu et al., 2020), pre-existing chronic diseases (Townsend et al., 2020), and socioeconomic and demographic (Abedi et al., 2020; Clouston et al., 2021; Karaye \& Horney, 
medRxiv preprint doi: https://doi.org/10.1101/2021.08.04.21261420; this version posted August 8, 2021. The copyright holder for this preprint (which was not certified by peer review) is the author/funder, who has granted medRxiv a license to display the preprint in perpetuity.

All rights reserved. No reuse allowed without permission.

2020), political (Neelon et al., 2021), behavioral (Badr et al., 2020; McGrail et al., 2020), and environmental (Chakrabarty et al., 2021; Wang et al., 2020) factors.

\subsubsection{Descriptive statistics of variables}

The descriptive statistics for each variable entered in the regression analysis are presented in Table 1 (See Table S3 for the descriptive information for all variables).

Table 1. Descriptive data for SARS-CoV-2 infection rates, socioeconomic and demographic, pre-existing chronic disease, policy and regulation, behavioral, built environment, and green space factors.

\begin{tabular}{|c|c|c|c|c|c|c|}
\hline Model Predictors & Variables & Min & Max & Mean & SD & Unit or Formula \\
\hline $\begin{array}{l}\text { SARS-CoV-2 } \\
\text { Infection rate }\end{array}$ & Infection rate & 420.885 & 27173.734 & 6570.950 & 2762.664 & Cases per $100 \mathrm{k}$ \\
\hline \multirow{7}{*}{$\begin{array}{l}\text { Socio-economic and } \\
\text { demographic } \\
\text { factors }\end{array}$} & Population density & 0.094 & 19625.842 & 98.221 & 559.972 & Persons per $\mathrm{km}^{2}$ \\
\hline & Black non-Hispanic & 0.000 & 87.400 & 8.957 & 14.520 & Ratio \\
\hline & Population aged $65+$ & 3.800 & 55.600 & 18.428 & 4.542 & Ratio \\
\hline & Gini Index & 0.257 & 0.665 & 0.446 & 0.036 & Range $0-1$ \\
\hline & Median home value & 21000.00 & 1057000.00 & 146157.40 & 89047.61 & USD\$ \\
\hline & Unemployment rate & 1.300 & 18.100 & 4.093 & 1.397 & Ratio \\
\hline & $\begin{array}{l}\text { Population without } \\
\text { high school diploma }\end{array}$ & 1.200 & 66.300 & 13.448 & 6.342 & Ratio \\
\hline \multirow{2}{*}{$\begin{array}{l}\text { Healthcare and } \\
\text { testing factors }\end{array}$} & Testing rate & 0.000 & 1711.099 & 170.197 & 107.693 & Per $100 \mathrm{k}$ \\
\hline & $\begin{array}{l}\text { Population without } \\
\text { insurance }\end{array}$ & 2.300 & 33.700 & 11.418 & 5.106 & Ratio \\
\hline \multirow[t]{5}{*}{$\begin{array}{l}\text { Pre-existing chronic } \\
\text { disease factors }\end{array}$} & $\begin{array}{l}\text { Heart failure } \\
\text { mortality }\end{array}$ & 19.400 & 304.300 & 108.314 & 25.488 & Per 100k \\
\hline & Stroke mortality & 14.000 & 92.500 & 39.776 & 8.153 & Per $100 \mathrm{k}$ \\
\hline & $\begin{array}{l}\text { Hypertension } \\
\text { morality }\end{array}$ & 19.300 & 587.300 & 131.825 & 55.366 & Per $100 \mathrm{k}$ \\
\hline & Diabetes rate & 2.200 & 28.700 & 10.506 & 3.526 & Ratio \\
\hline & Obesity rate & 12.30 & 57.90 & 32.76 & 5.68 & Ratio \\
\hline \multirow[t]{4}{*}{$\begin{array}{l}\text { Policy and } \\
\text { regulation factors }\end{array}$} & State Governor Party & 0.000 & 1.000 & 0.435 & 0.496 & $\begin{array}{l}\text { Democratic } \\
\text { /Republican }\end{array}$ \\
\hline & Stay-at-home orders & 3.856 & 6.897 & 4.441 & 0.447 & Range 1-7 \\
\hline & $\begin{array}{l}\text { Public mask } \\
\text { mandates }\end{array}$ & 0.000 & 1.000 & 0.497 & 0.339 & Yes/No \\
\hline & $\begin{array}{l}\text { Business closing and } \\
\text { reopening }\end{array}$ & 4.781 & 8.233 & 6.331 & 0.683 & Range $1-5$ \\
\hline \multirow[t]{7}{*}{ Behavioral factors } & Smoker & 5.909 & 41.491 & 17.446 & 3.554 & Ratio \\
\hline & Essential worker & 0.178 & 0.791 & 0.526 & 0.073 & Ratio \\
\hline & POI visits & 0.000 & 10.507 & 1.505 & 0.904 & Per person \\
\hline & $\begin{array}{l}\text { Commute to work by } \\
\text { walking or bicycle }\end{array}$ & 0.000 & 42.410 & 3.427 & 3.146 & Ratio \\
\hline & $\begin{array}{l}\text { Leisure time physical } \\
\text { inactivity }\end{array}$ & 9.400 & 49.800 & 26.238 & 5.498 & Ratio \\
\hline & Mobility & 0.409 & 553.723 & 8.118 & 14.190 & $\mathrm{Km}$ \\
\hline & Mobility index & 17.156 & 947.757 & 79.520 & 40.596 & Ratio \\
\hline \multirow[t]{4}{*}{$\begin{array}{l}\text { Environmental } \\
\text { factors }\end{array}$} & $\begin{array}{l}\text { Severe housing } \\
\text { problems }\end{array}$ & 2.700 & 39.100 & 14.308 & 4.338 & Ratio \\
\hline & $\begin{array}{l}\text { Overcrowded } \\
\text { Housing }\end{array}$ & 0.000 & 16.900 & 2.314 & 1.816 & Ratio \\
\hline & Proximity to highway & 0.000 & 16.400 & 1.943 & 1.871 & Ratio \\
\hline & Airport density & 0.000 & 0.039 & 0.002 & 0.002 & Number per $\mathrm{km}^{2}$ \\
\hline
\end{tabular}


medRxiv preprint doi: https://doi.org/10.1101/2021.08.04.21261420; this version posted August 8, 2021. The copyright holder for this preprint (which was not certified by peer review) is the author/funder, who has granted medRxiv a license to display the preprint in perpetuity.

All rights reserved. No reuse allowed without permission.

\begin{tabular}{|c|c|c|c|c|c|c|}
\hline & Railway density & 0.000 & 2.625 & 0.062 & 0.111 & $\begin{array}{l}\text { Length of } \mathrm{km} \text { per } \\
\mathrm{km}^{2}\end{array}$ \\
\hline & $\begin{array}{l}\text { Highway and } \\
\text { secondary road } \\
\text { density }\end{array}$ & 0.000 & 1.577 & 0.105 & 0.132 & $\begin{array}{l}\text { Length of } \mathrm{km} \text { per } \\
\mathrm{km}^{2}\end{array}$ \\
\hline & PM2.5 & 1.500 & 16.000 & 7.640 & 1.674 & $\mathrm{Kj}$ per $\mathrm{m}^{2}$ \\
\hline & PM10 & 7.476 & 57.922 & 17.417 & 4.755 & $\mathrm{Ug} / \mathrm{m}^{3}$ \\
\hline & $\mathrm{NO}_{2}$ & 2.896 & 27.402 & 13.321 & 3.337 & $\mathrm{Ppb}$ \\
\hline & Average temperature & 36.809 & 79.218 & 57.687 & 7.941 & Degrees Fahrenheit \\
\hline & Wind speed & 3.969 & 9.923 & 7.026 & 0.800 & $\mathrm{~m} / \mathrm{s}$ \\
\hline \multirow[t]{6}{*}{ Green space factors } & $\begin{array}{l}\text { Developed open } \\
\text { space }\end{array}$ & 0.001 & 0.337 & 0.045 & 0.039 & $\begin{array}{l}\text { Developed open } \\
\text { space area/ county } \\
\text { area }\end{array}$ \\
\hline & Forest & 0.000 & 0.929 & 0.306 & 0.256 & $\begin{array}{l}\text { Forest area/county } \\
\text { area }\end{array}$ \\
\hline & Shrub / Scrub & 0.000 & 0.976 & 0.085 & 0.181 & $\begin{array}{l}\text { Shrub and scrub } \\
\text { area/county area }\end{array}$ \\
\hline & $\begin{array}{l}\text { Grassland/ } \\
\text { Herbaceous }\end{array}$ & 0.000 & 0.977 & 0.094 & 0.169 & $\begin{array}{l}\text { Grassland or } \\
\text { herbaceous } \\
\text { area/county area }\end{array}$ \\
\hline & Hay / Pasture & 0.000 & 0.799 & 0.101 & 0.123 & $\begin{array}{l}\text { Pasture and hay } \\
\text { area/county area }\end{array}$ \\
\hline & Local parks & 0.000 & 0.143 & 0.002 & 0.009 & $\begin{array}{l}\text { Local park } \\
\text { area/county area }\end{array}$ \\
\hline
\end{tabular}

\subsection{Statistical analysis}

Prior to analyses, the variance inflation factor (VIF) test was used to identify multicollinearity between the independent variables. All factors with a VIF $\geq 4$ were excluded from our models (O'Brien, 2007). We employed hierarchical linear regression to address our research questions in four steps, as follows.

(1) The overall associations between infection rates and green space factors were examined using two regression models. Model 1 included confounding factors only, while Model 2 included green space factors and confounding factors. This allowed us to identify the independent effect of green space factors on infection rates, while controlling for confounders.

(2) We examined whether green space-infection associations varied in different time periods and at different urbanicity levels using ten regression models. Similar to the step one, for each period or urbanicity level, Model 1 included only confounding factors, while Model 2 included green space factors and confounders. Model $\beta, R^{2}$, and $\Delta R^{2}$ values were reported. 
(3) The results from steps 1 and 2 revealed that forest has a consistent and strong association with infection rates. We further explored the temporality of forest-infection associations across five urbanicity levels. Regression analyses were conducted to evaluate the effect of forest on infection rates for all 25 combinations of the five time periods and five urbanicity levels. For each combination, Model 1 included all confounding factors and green space factors except forest, while Model 2 also included forest. The $\beta, R^{2}$, and $\Delta R^{2}$ values were reported for each model (Table S4 and S5).

(4) To identify the optimal distance from forest, we used a series of hierarchical linear regressions to examine the association between population-weighted forest exposure, for distances ranging from $100 \mathrm{~m}$ to $50 \mathrm{~km}$, and the infection rate. For each buffer distance, Model 1 included all confounding factors and green space factors except forest, while Model 2 included populationweighted forest exposure. The $p$ values, 95\% confidence intervals $(\mathrm{CI})$, and $R^{2}$ and $\Delta R^{2}$ values were reported (Table S6).

All analyses were performed using $R$-4.0.5 with the built-in " $1 \mathrm{~m}$ " function (R Core Team, 2020). 


\section{Results}

\subsection{Overall association of green spaces with infection rates}

The results of a hierarchical regression analysis are shown in Table 2. Model 1 included all confounding factors and explained $45.1 \%$ of the variability in infection rates (adjusted $R^{2}=0.451$, $p<0.0001)$. After adding the green space factors, the overall explanatory power of Model 2 increases by $5.5 \%$ (adjusted $R^{2}=0.506, p<0.0001$ ). The individual effects of the six types of green spaces, after controlling for confounders, revealed that forest and hay/pasture are significantly, negatively associated with overall infection rates $(p<0.0001)$ (Fig. 4). Shrub/scrub and local parks are negatively associated with infection rates at a marginally significant level $(p<$ $0.05)$. Developed open space is significantly positively associated with infection rates $(p<0.001)$. Among all types of green space, forest has the greatest effect on infection rates $(\beta=-0.305)$. 
medRxiv preprint doi: https://doi.org/10.1101/2021.08.04.21261420; this version posted August 8, 2021. The copyright holder for this preprint (which was not certified by peer review) is the author/funder, who has granted medRxiv a license to display the preprint in perpetuity. All rights reserved. No reuse allowed without permission.

Table 2. Regression analysis results of overall associations between green spaces and infection rate $(N=3108)$.

\begin{tabular}{|c|c|c|c|}
\hline Category of factors & Factors & Model 1 & Model 2 \\
\hline \multirow{7}{*}{$\begin{array}{l}\text { Socioeconomic and } \\
\text { demographic factors }\end{array}$} & Population density & $0.015(-0.020,0.051)$ & $0.022(-0.016,0.060)$ \\
\hline & Black non-Hispanic & $0.091(0.052,0.130)^{* * *}$ & $0.018(-0.021,0.056)$ \\
\hline & Population aged $65+$ & $-0.167(-0.202,-0.132)^{* * *}$ & $-0.126(-0.159,-0.092)^{* * *}$ \\
\hline & Gini Index & $0.080(0.046,0.114)^{* * *}$ & $0.082(0.049,0.115)^{* * *}$ \\
\hline & Median home value & $-0.106(-0.153,-0.059)^{* * *}$ & $-0.045(-0.090,0.001)$ \\
\hline & Unemployment rate & $-0.098(-0.135,-0.062)^{* * *}$ & $-0.066(-0.101,-0.030)^{* *}$ \\
\hline & Population without high school diploma & $0.121(0.071,0.171)^{* * *}$ & $0.148(0.100,0.195)^{* * *}$ \\
\hline \multirow{2}{*}{$\begin{array}{l}\text { Healthcare and testing } \\
\text { factors }\end{array}$} & Population without insurance & $-0.008(-0.054,0.038)$ & $-0.003(-0.049,0.043)$ \\
\hline & Testing rate & $0.341(0.311,0.371)^{* * *}$ & $0.315(0.286,0.344)^{* * *}$ \\
\hline \multirow{5}{*}{$\begin{array}{l}\text { Pre-existing chronic } \\
\text { disease factors }\end{array}$} & Diabetes rate & $-0.005(-0.041,0.031)$ & $0.013(-0.021,0.047)$ \\
\hline & Obesity rate & $0.005(-0.032,0.041)$ & $-0.024(-0.059,0.011)$ \\
\hline & Stroke mortality & $0.007(-0.030,0.043)$ & $0.011(-0.023,0.046)$ \\
\hline & Hypertension mortality & $0.005(-0.028,0.038)$ & $0.006(-0.025,0.038)$ \\
\hline & Heart disease mortality & $0.022(-0.013,0.057)$ & $0.033(-0.001,0.066)$ \\
\hline \multirow[t]{7}{*}{ Behavioral factors } & Smoker & $0.042(-0.001,0.085)$ & $0.092(0.051,0.133)^{* * *}$ \\
\hline & Essential worker & $0.046(0.003,0.089)^{\dagger}$ & $0.077(0.035,0.119)^{* *}$ \\
\hline & POI visits & $0.096(0.065,0.126)^{* * *}$ & $0.091(0.062,0.120)^{* * *}$ \\
\hline & Commute to work by walking or bicycle & $-0.057(-0.091,-0.024)^{* *}$ & $-0.077(-0.109,-0.045)^{* * *}$ \\
\hline & Leisure time physical inactivity & $0.060(0.021,0.100)^{*}$ & $0.033(-0.005,0.071)$ \\
\hline & Mobility & $-0.010(-0.037,0.017)$ & $0.003(-0.024,0.029)$ \\
\hline & Mobility 50index & $0.027(-0.002,0.056)$ & $0.026(-0.002,0.054)$ \\
\hline \multirow{4}{*}{$\begin{array}{l}\text { Policy and regulation } \\
\text { factors }\end{array}$} & State governor party & $0.056(0.014,0.098)^{*}$ & $0.010(-0.031,0.051)$ \\
\hline & Stay-at-home orders & $0.012(-0.020,0.044)$ & $0.002(-0.029,0.032)$ \\
\hline & Public mask mandates & $-0.215(-0.258,-0.173)^{* * *}$ & $-0.164(-0.205,-0.122)^{* * *}$ \\
\hline & Business closing and reopening & $-0.137(-0.169,-0.104)^{* * *}$ & $-0.138(-0.170,-0.107)^{* * *}$ \\
\hline \multirow[t]{11}{*}{ Environmental factors } & Severe housing problem & $-0.200(-0.242,-0.158)^{* * *}$ & $-0.153(-0.193,-0.112)^{* * *}$ \\
\hline & Overcrowded Housing & $0.157(0.116,0.199)^{* * *}$ & $0.120(0.080,0.160)^{* * *}$ \\
\hline & Proximity to highway & $0.011(-0.021,0.043)$ & $0.023(-0.007,0.054)$ \\
\hline & Airport density & $-0.038(-0.067,-0.009)^{\dagger}$ & $-0.086(-0.115,-0.057)^{* * *}$ \\
\hline & Railway density & $-0.015(-0.052,0.021)$ & $-0.039(-0.074,-0.004)^{\dagger}$ \\
\hline & Highway and secondary road density & $0.009(-0.034,0.052)$ & $-0.054(-0.101,-0.007)^{\dagger}$ \\
\hline & PM 2.5 & $0.001(-0.037,0.040)$ & $0.084(0.043,0.125)^{* *}$ \\
\hline & PM 10 & $0.255(0.219,0.290)^{* * *}$ & $0.120(0.079,0.160)^{* * *}$ \\
\hline & $\mathrm{NO}_{2}$ & $-0.027(-0.062,0.008)$ & $-0.018(-0.052,0.016)$ \\
\hline & Average temperature & $-0.200(-0.248,-0.151)^{* * *}$ & $-0.239(-0.286,-0.192)^{* * *}$ \\
\hline & Wind speed & $0.088(0.053,0.123)^{* * *}$ & $0.026(-0.008,0.060)$ \\
\hline \multirow[t]{6}{*}{ Green space factors } & Developed open space & \multirow{6}{*}{ N/A } & $0.084(0.041,0.128)^{* *}$ \\
\hline & Forest & & $-0.305(-0.343,-0.268)^{* * *}$ \\
\hline & Shrub / Scrub & & $-0.043(-0.081,-0.006)^{\dagger}$ \\
\hline & Grassland / Herbaceous & & $0.038(0.004,0.073)^{\dagger}$ \\
\hline & Hay / Pasture & & $-0.066(-0.096,-0.035)^{* * *}$ \\
\hline & Local parks & & $-0.049(-0.086,-0.011)^{\dagger}$ \\
\hline
\end{tabular}


medRxiv preprint doi: https://doi.org/10.1101/2021.08.04.21261420; this version posted August 8, 2021. The copyright holder for this preprint (which was not certified by peer review) is the author/funder, who has granted medRxiv a license to display the preprint in perpetuity.

All rights reserved. No reuse allowed without permission.

\subsection{Green space-infection rate associations across levels of urbanicity}

We divided all data by five levels of urbanicity, and ran separate regression models to explore the extent to which green space-infection associations varied by urbanicity (Table S4 and Fig. 5). We found that the additional explanatory power contributed by green spaces, indicated by $\Delta R^{2}$, is significant for all levels of urbanicity. The highest $\Delta R^{2}$ is seen for urbanicity level $3(9.2 \%)$, while the two extremes of urbanicity level have the lowest (level 1:2.9\%; level 5: 3.3\%). As seen in Fig. 5 , forest is the only type of green spaces that significantly associated with infection rates across all five levels of urbanicity, with its association being strongest at level $3(\beta=-0.431, p<0.0001)$.
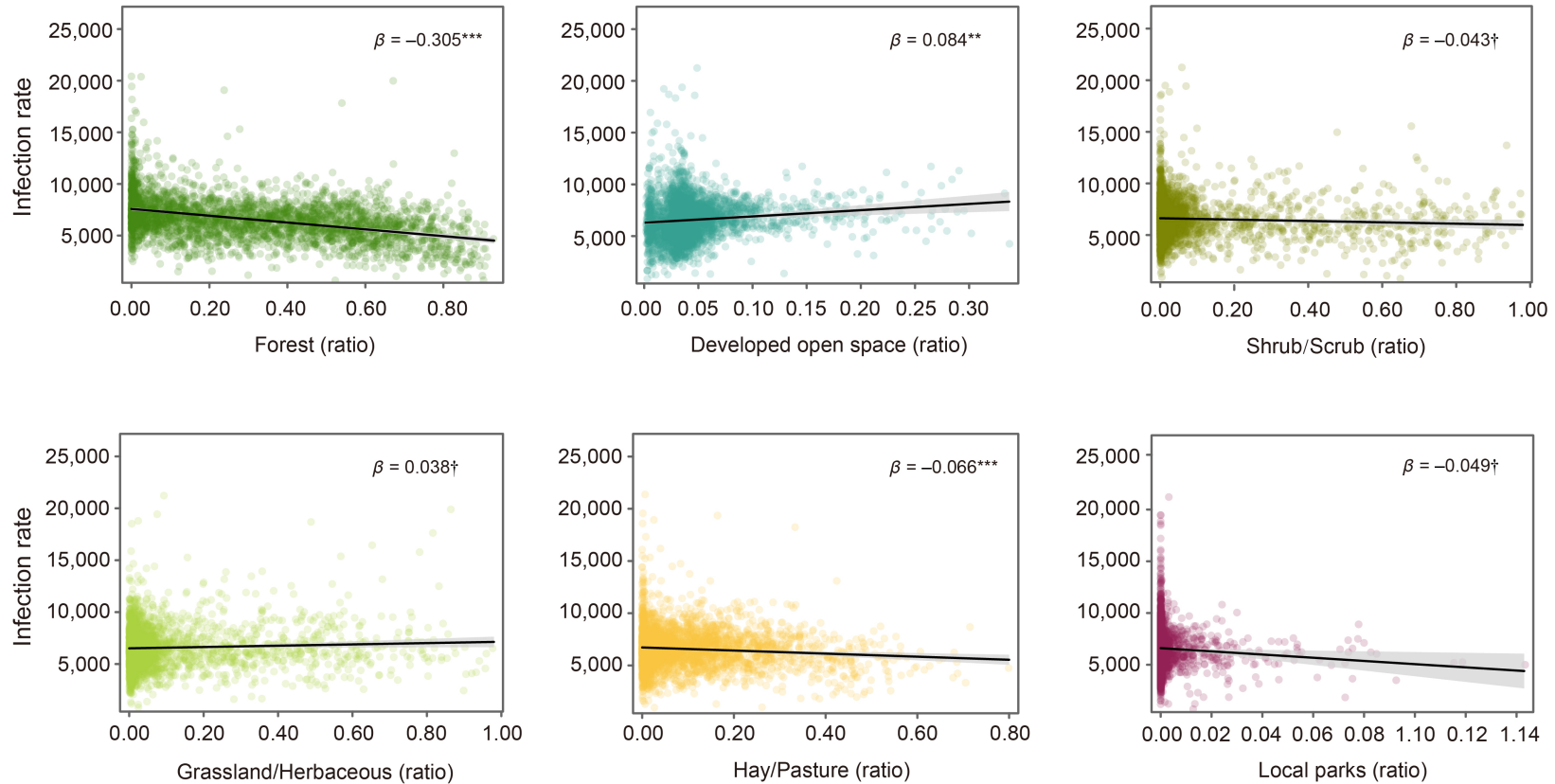

Fig. 4. Relationships between each of the six types of green spaces and SARS-CoV-2 infection rates. Each green space factor ratio is calculated by dividing green space area by the total area of the county. Shaded areas represent pointwise $95 \%$ confidence intervals, points represent partial residuals. Lines represent the linear trend line. Note: ${ }^{\dagger} p<0.05 ;{ }^{*} p<0.01 ;{ }^{* *} p<0.001 ;{ }^{* * *} p<$ 0.0001 . 
medRxiv preprint doi: https://doi.org/10.1101/2021.08.04.21261420; this version posted August 8, 2021. The copyright holder for this preprint (which was not certified by peer review) is the author/funder, who has granted medRxiv a license to display the preprint in perpetuity. All rights reserved. No reuse allowed without permission.

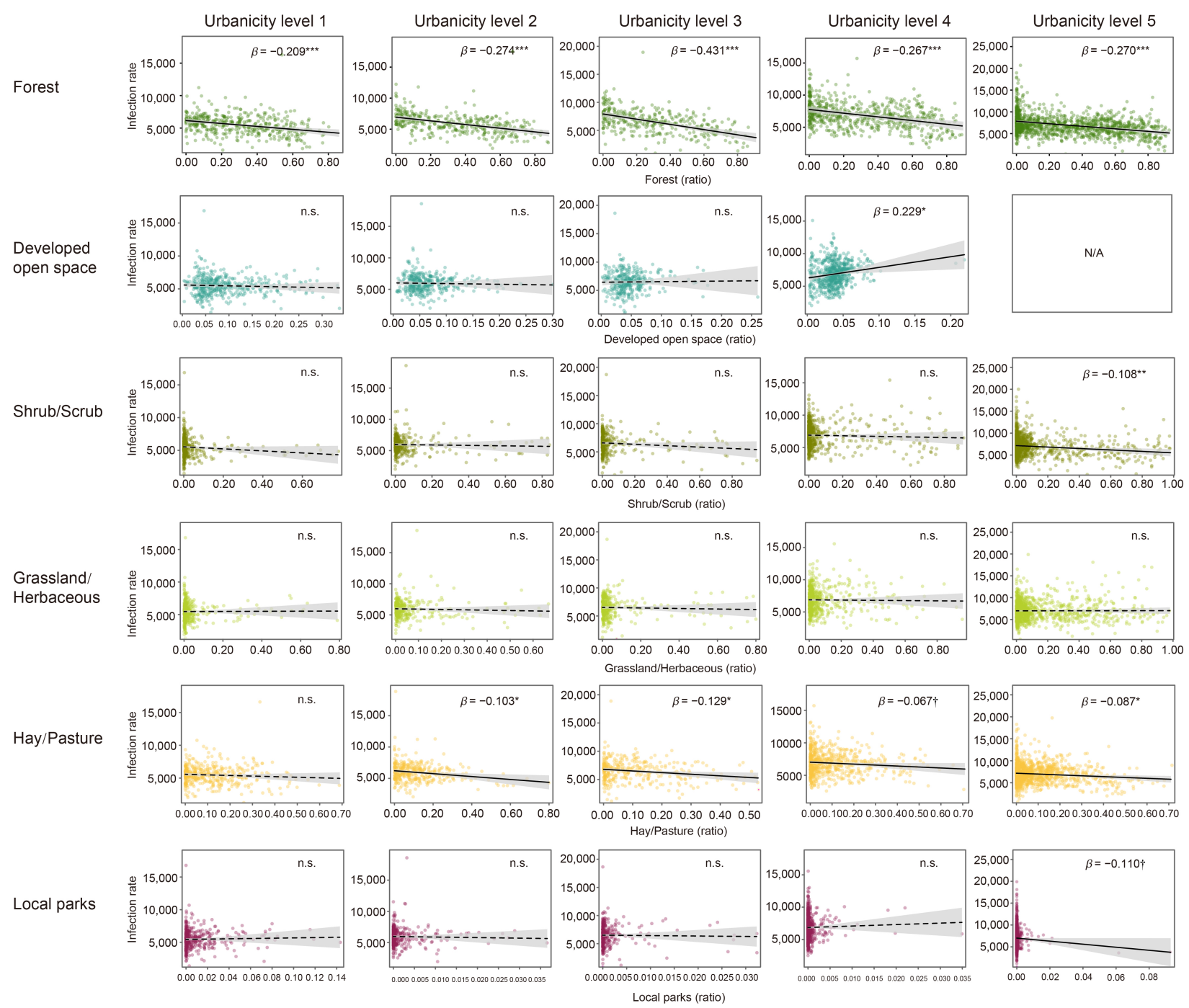

Fig. 5. The association of six types of green spaces with SARS-CoV-2 infection rates across five levels of urbanicity. Each green space factor is calculated by dividing green space area by the total area of the county. Shaded areas represent the pointwise $95 \%$ confidence intervals. Points represent partial residuals. Lines represent the linear trend lines. A solid line indicates a statistically significant relationship, whereas a dashed line indicates a non-significant relationship. Note: ${ }^{\dagger} p<0.05 ;{ }^{*} p<0.01 ;{ }^{* *} p<0.001 ;{ }^{* * *} p<0.0001$.

\subsection{Green space-infection rate associations across time periods}

Next, we fitted five regression models to five time periods to explore temporal variations in green space-infection associations (Table $\mathrm{S} 5)$. The additional explanatory power $\left(\Delta R^{2}\right)$, resulting from the including green space factors, is significant across all time periods, and gradually increases from period 1 to period 5 (from $0.3 \%$ to $5.0 \%$ ). Fig. 6 shows the individual effects of six different types of green space on SARS-CoV-2 infection rates for each the five time periods. Note that forest 
medRxiv preprint doi: https://doi.org/10.1101/2021.08.04.21261420; this version posted August 8, 2021. The copyright holder for this preprint (which was not certified by peer review) is the author/funder, who has granted medRxiv a license to display the preprint in perpetuity. All rights reserved. No reuse allowed without permission.

is significantly negatively associated with infection rates across all periods, except period 1, with the effect size increasing from period 2 to 5.
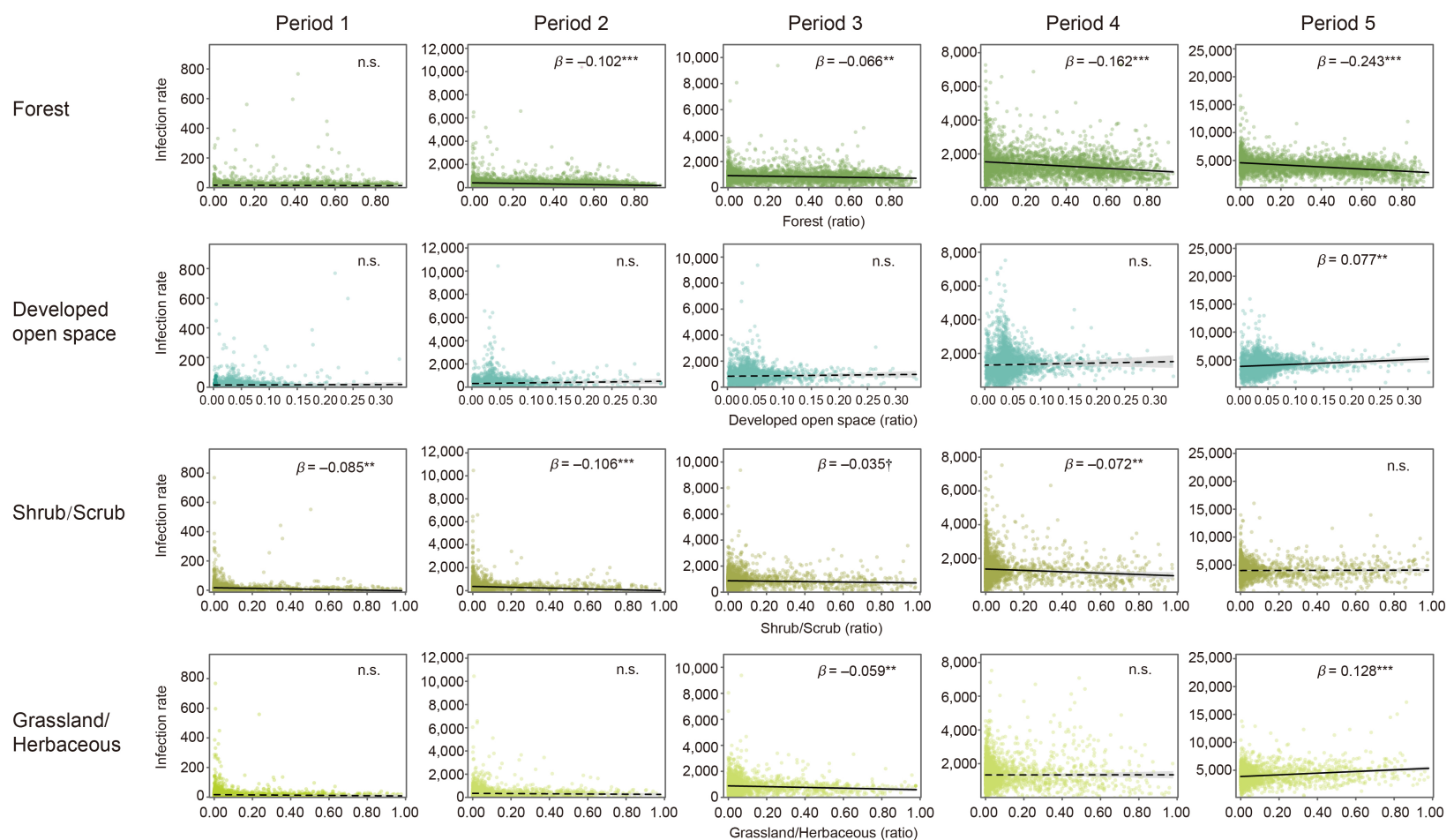

Hay/Pasture
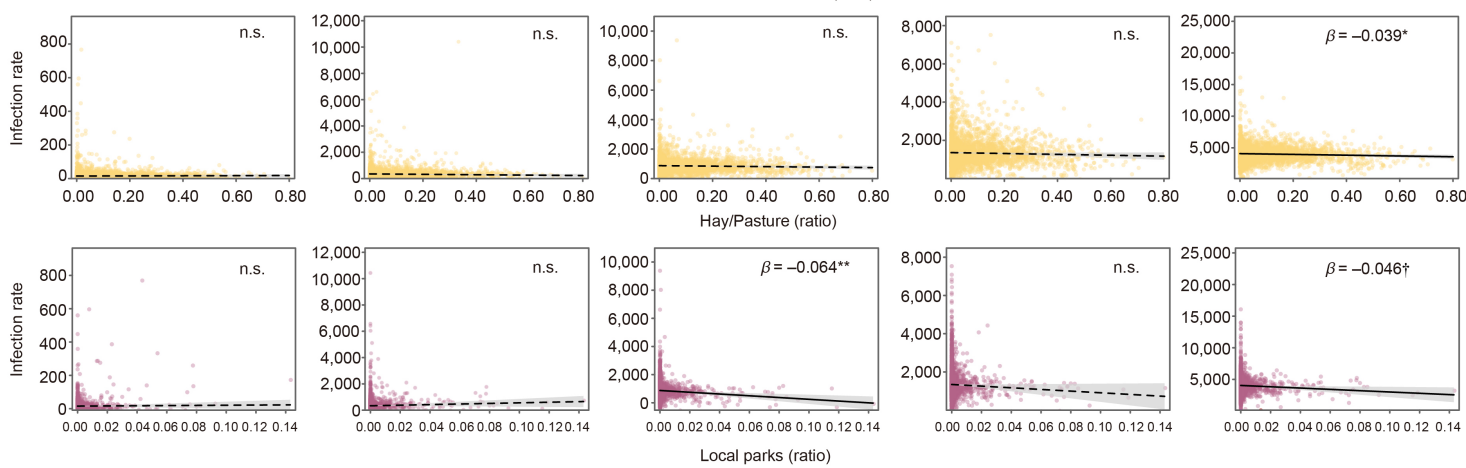

Fig. 6. The effects of six types of green space on SARS-CoV-2 infection rates across five time periods. Each green space factor is calculated by dividing green space area by the total area of the county. Shaded areas represent pointwise $95 \%$ confidence intervals. Points represent partial residuals. Lines represent the linear trend line. Note: ${ }^{\dagger} p<0.05 ;{ }^{*} p<0.01 ;{ }^{* *} p<0.001 ;{ }^{* * *} p<$ 0.0001. Period 1: January 22 to March 30, 2020. Period 2: March 31 to June 7, 2020. Period 3: June 8 to August 15, 2020. Period 4: August 16 to October 23, 2020. Period 5: October 24 to December 31, 2020. 
medRxiv preprint doi: https://doi.org/10.1101/2021.08.04.21261420; this version posted August 8, 2021. The copyright holder for this preprint (which was not certified by peer review) is the author/funder, who has granted medRxiv a license to display the preprint in perpetuity.

All rights reserved. No reuse allowed without permission.

\subsection{Forest-infection rate associations across five levels of urbanicity and five time periods}

Given that forest has the most consistent and significant association with infection rates, we next examined the spatiotemporal patterns of the forest-infection rate association for 25 combinations of urbanicity levels and time periods. These associations, after controlling for all confounding factors, were presented in Table S6 and Fig. 7. Notice in Table S6 that the $\beta$ values increases with successive periods across all urbanicity levels. Forest is significantly and negatively associated with infection rates at nearly all urbanicity levels in periods 4 and 5 . Here again, the association of forest with infection rates is greatest at Urbanicity level $3(\beta=-0.256$ and -0.244 at time periods 4 and 5 , respectively). 
medRxiv preprint doi: https://doi.org/10.1101/2021.08.04.21261420; this version posted August 8, 2021. The copyright holder for this preprint (which was not certified by peer review) is the author/funder, who has granted medRxiv a license to display the preprint in perpetuity. All rights reserved. No reuse allowed without permission.
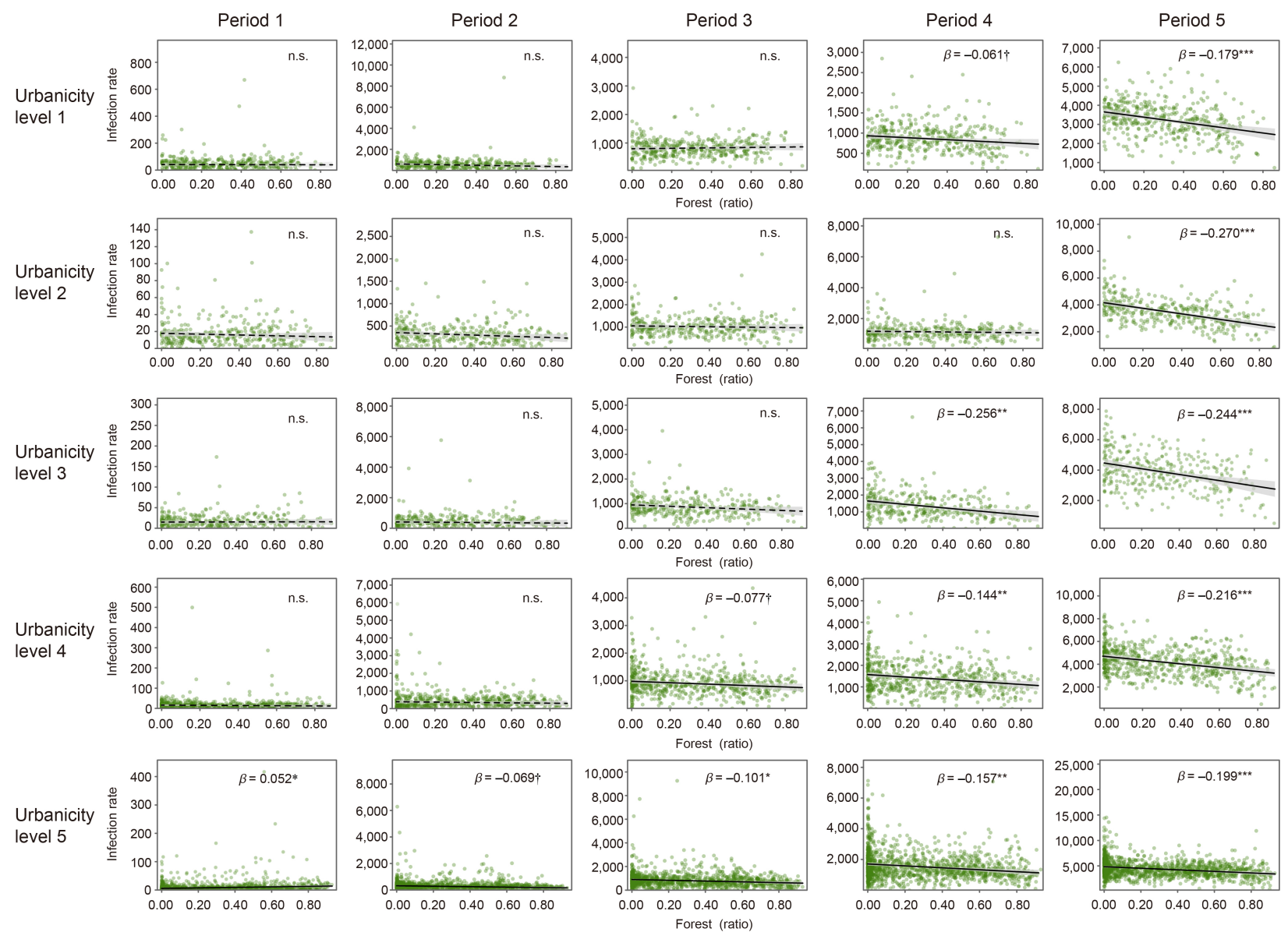

Fig. 7. The spatiotemporal effects of forests on SARS-CoV-2 infection rates across five levels of urbanicity and five time periods. Shaded areas represent the pointwise $95 \%$ confidence intervals. Points represent partial residuals. Lines represent the linear trend lines. Note: ${ }^{\dagger} p<0.05 ;{ }^{*} p<0.01 ;{ }^{* *} p<0.001 ;{ }^{* * *} p<0.0001$. 
medRxiv preprint doi: https://doi.org/10.1101/2021.08.04.21261420; this version posted August 8, 2021. The copyright holder for this preprint (which was not certified by peer review) is the author/funder, who has granted medRxiv a license to display the preprint in perpetuity.

All rights reserved. No reuse allowed without permission.

\subsection{Associations of population-weighted forest at varying distances with infection rates}

Although these results revealed that forest has a negative association with infection rates at the county scale, the impact of the distance between forest and human settlements on this association is unclear. Thus, we now examined the association of population-weighted forest at various buffer distances (from $100 \mathrm{~m}$ to $50 \mathrm{~km}$ ) with infection rates (Fig. 8).
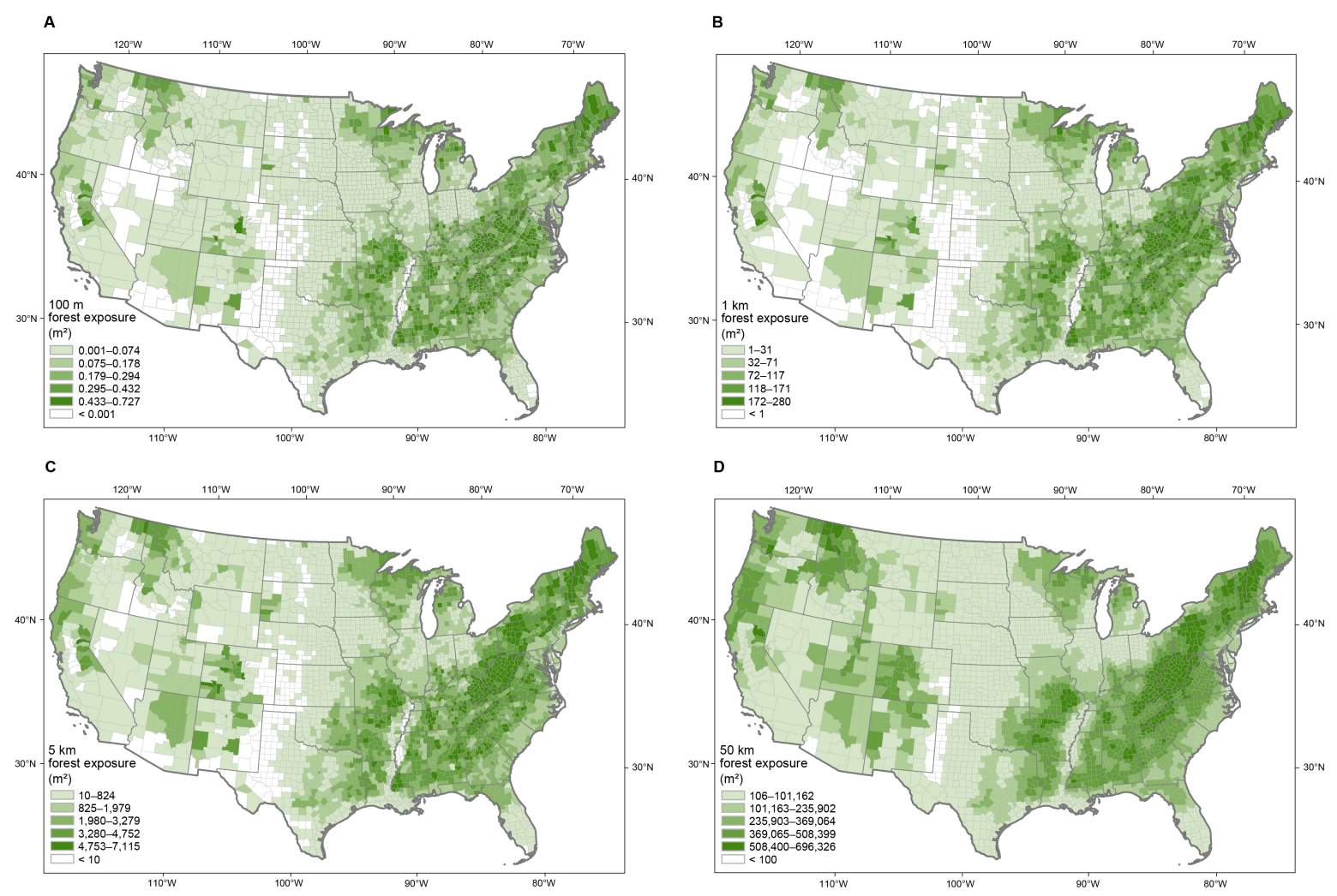

Fig. 8. Population-weighted forest exposure at varying buffer distances at the county level. Population-weighted exposure to the nearest forest within a (A) 100-m, (B) 1-km, (C) 5-km, or (D) 50-km buffer distance at the county level. All population-weighted forest exposure values were calculated using Google Earth Engine.

First, we examined the relationship between forest within walking distance $(0-5 \mathrm{~km})$ with infection rates. This 5-km buffer distance is regarded as the longest reasonable walking distance for people in the United States (Yang \& Diez-Roux, 2012). The effect size $(\beta)$ and explanatory power (adjusted $R^{2}$ ) of population-weighted forest exposures for various buffer distances were presented in Fig 8. The curves suggest a pattern of diminishing marginal effects. As Table S7 shows, the 
medRxiv preprint doi: https://doi.org/10.1101/2021.08.04.21261420; this version posted August 8, 2021. The copyright holder for this preprint (which was not certified by peer review) is the author/funder, who has granted medRxiv a license to display the preprint in perpetuity.

All rights reserved. No reuse allowed without permission.

closest forest (within $100 \mathrm{~m}$ ) contributed significantly to the overall effects seen for forest $(\beta$ values: -0.250 vs $-0.305,82.0 \%$; adjusted $\Delta R^{2}$ by forest: 0.029 vs $0.041,70.7 \%$ ).

With increasing buffer distance, the beneficial effects of forest exposure increase, however the extent of these increases gradually attenuates. At moderate buffer distances $(\leq 1.0-1.4 \mathrm{~km}$ or $12.5-$ $17.5 \mathrm{~min}$ given an average walking speed of $80 \mathrm{~m} / \mathrm{min}$ ), the effects of forest exposure reach a plateau, whereby further increases in buffer distance did not lead to further significant beneficial associations (Fig. 9 and Table S7). Compared to overall forest exposure, exposure to forest within a 1.0-1.4-km buffer distance is associated with the greatest reduction in infection rates within the optimal $5 \mathrm{~km}$ walking radius (e.g., for $1.0 \mathrm{~km}$ : $\beta$ values: -0.273 vs $-0.305,89.5 \%$; adjusted $R^{2}$ change by forest: 0.033 vs $0.041,80.4 \%$ ). This optimal walking distance is within the preferred maximum walking distance in the United States (Yang \& Diez-Roux, 2012). 
medRxiv preprint doi: https://doi.org/10.1101/2021.08.04.21261420; this version posted August 8, 2021. The copyright holder for this preprint (which was not certified by peer review) is the author/funder, who has granted medRxiv a license to display the preprint in perpetuity.

All rights reserved. No reuse allowed without permission.
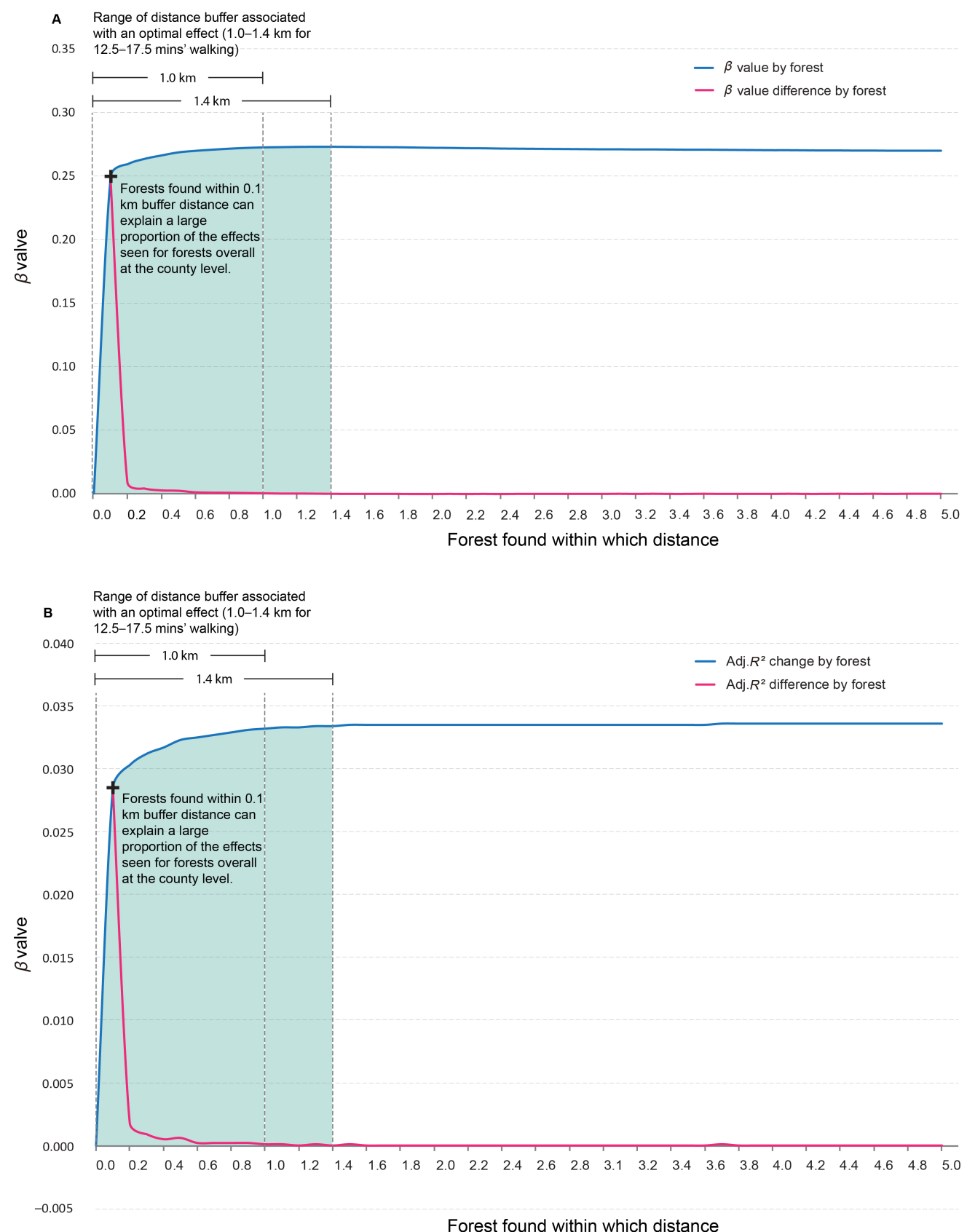

Fig. 9. The effects of forest within walking distance $(0-5 \mathrm{~km})$ on infection rates. The effects are indicated by the $\beta$ values and adjusted $R^{2}$ values explained by forest in the regression models. The (A) $\beta$ and (B) adjusted $R^{2}$ values for forest exposure (blue line) continue to increase with increasing distances, however the size of the increments (shown in pink line) plateau with increasing distance. 
We next investigated the association between forest beyond walking distance $(5-50 \mathrm{~km})$ and infection rate. The growth of $\beta$ and incremental $R^{2}$ remained small and stable as the buffer distance increases (Fig. 10 and Table S7). The curves for both $\beta$ and incremental $R^{2}$ plateau with a slight positive slope. Nevertheless, compared to forest falling within the 5-km walking range, we found that forest further afield is also related to infection rates, although the association is relatively minor. Using $50-\mathrm{km}$ and $1.0-\mathrm{km}$ distances for comparison, $\beta$ values are -0.290 and -0.273 , respectively, suggesting a $6.2 \%$ increase in the effect. Similarly, the adjusted $R^{2}$ values are 0.036 and 0.033 , respectively, suggesting a $9.1 \%$ increase in the effect. The proportion of the changes in $\beta$ and adjusted $R^{2}$ values accounted for by forest within $50 \mathrm{~km}$ relative to all forest in the county were $95.1 \%$ and $87.8 \%$, respectively. 
medRxiv preprint doi: https://doi.org/10.1101/2021.08.04.21261420; this version posted August 8, 2021. The copyright holder for this preprint (which was not certified by peer review) is the author/funder, who has granted medRxiv a license to display the preprint in perpetuity.

All rights reserved. No reuse allowed without permission.

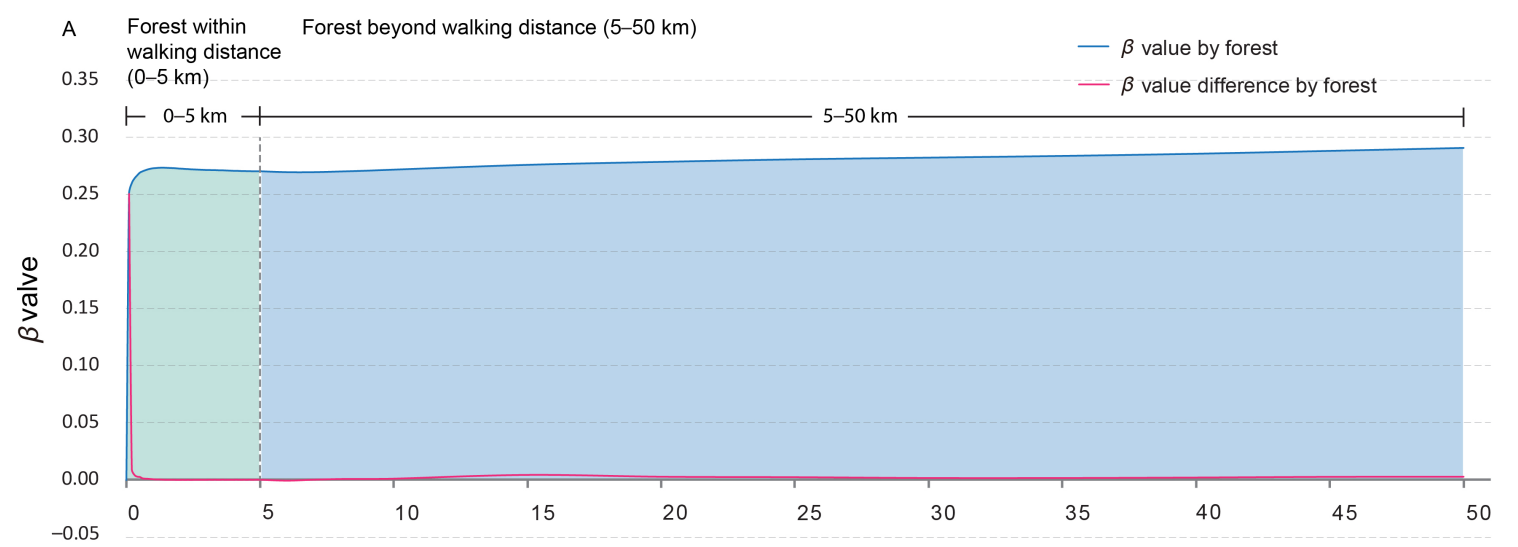

Forest found within which distance

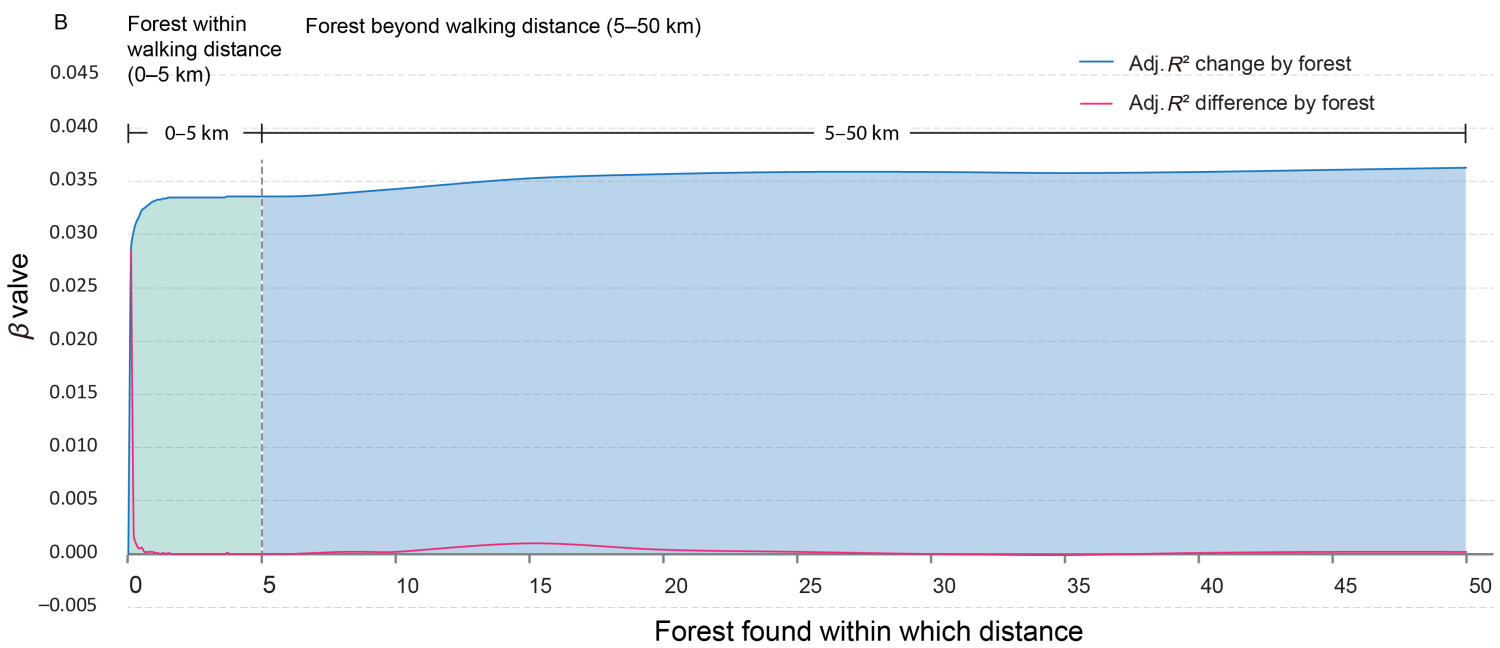

Fig. 10. The effects of forest at varying buffer distances on infection rates (0-5 $\mathbf{~ k m}$ and $\mathbf{5 - 5 0} \mathbf{~ k m})$. Effects were determined by the $\beta$ values and adjusted $R^{2}$ values explained by forest in the regression models. For both $\beta$ and adjusted $R^{2}$ values, the portion of curves beyond walking distance $(5-50 \mathrm{~km})$ plateaued, with a slight positive slope. Nevertheless, compared to forest within the 5-km walking range, the forest further away could also reduce infection rates, although the effect was relatively minor. 
medRxiv preprint doi: https://doi.org/10.1101/2021.08.04.21261420; this version posted August 8, 2021. The copyright holder for this preprint (which was not certified by peer review) is the author/funder, who has granted medRxiv a license to display the preprint in perpetuity.

All rights reserved. No reuse allowed without permission.

\section{Discussion}

This study examined the association between green spaces and one-year of SARS-CoV-2 infection rates across all 3,108 counties in the contiguous United States after controlling for multiple categories of confounding factors. There were five major findings : (1) collectively, green spaces have an inverse association with SARS-CoV-2 infection rates; (2) forest has a stronger negative association with infection rates than all other types of green spaces; (3) the association between forest and infection rates is strongest for counties with a moderate level of urbanicity although the association remain significant for all five levels of urbanicity; (4) the association between forest and infection rates became stronger over the five time periods examined, and was strongest for the most recent time period when infection rates were at their highest; and (5) these associations can be largely explained by the presence of nearby forest within a moderate walking distance $\left(\leq 1.0_{-}\right.$ $1.4 \mathrm{~km}$ or about $12.5-17.5$ minutes of walking on average).

In the following sections, we proposed key mechanisms to explain these main findings. We also discussed the novel contributions and implications of our findings. Finally, we discussed the limitations of this study and considered opportunities for future research.

\subsection{How might green spaces reduce SARS-CoV-2 infection rates?}

Before discussing potential mechanisms for reduced infection rates, it is important to note that the primary pathway of SARS-CoV-2 transmission is via aerosol particles (Klompas et al., 2020; Zhang, Li, Zhang, Wang, \& Molina, 2020). Thus, people are primarily infected with SARSCoV-2 by inhaling virus-containing droplets and aerosols exhaled by a human host (Bourouiba, 2020). Thus, compared to being indoors, being outdoors can reduce the risk of transmitting SARSCoV-2 in two ways. First, outdoor environments often provide much stronger natural air 
medRxiv preprint doi: https://doi.org/10.1101/2021.08.04.21261420; this version posted August 8, 2021. The copyright holder for this preprint (which was not certified by peer review) is the author/funder, who has granted medRxiv a license to display the preprint in perpetuity.

All rights reserved. No reuse allowed without permission.

movement, significantly reducing virus concentrations compared to indoor settings. In fact, a recent review suggested that the majority of SARS-CoV-2 infection clusters occurred in indoor settings (Leclerc et al., 2020). Second, outdoor environments, including large areas of green space, can support safer physical distancing, which reduces infection risks (Leclerc et al., 2020).

We found that, in general, green spaces were significantly inversely associated with SARS-CoV2 infection rates, even after controlling for confounding factors. Although regression models can only reveal associations, rather than causal relationships, we propose five mechanisms by which these effects could be explained.

\subsubsection{Mechanisms underlying reduced infection rates}

(1) Encouraging outdoor activities. Green spaces, especially those with sufficient recreational opportunities and supporting facilities, can be regarded as a "socio-pedal", in that they encourage people to leave indoor environments and participate in outdoor activities (Lu, Chen, et al., 2021; Lu, Zhao, et al., 2021; Schipperijn et al., 2013). One study reported that public spaces with more green landscapes can attract $90 \%$ more users than architecturally similar but barren public spaces (Sullivan et al., 2004). Similar findings have been reported by other studies (Chen et al., 2016; Liu et al., 2016). Social interaction is an essential aspect of human nature that can be suppressed for a short time, but cannot be sustained for long periods of time. Inevitably, despite restrictions on movement and socializing during the COVID-19 pandemic, people are likely to have had social gatherings in either indoor or outdoor settings (Geng et al., 2021). Green spaces not only invite people visit the outdoors more frequently (Coley, et al., 1997), but also seem to encourage them stay outdoors longer, reducing their time spent indoors (Braubach et al., 2017; Coley et al., 1997; Grahn \& Stigsdotter, 2003). 
medRxiv preprint doi: https://doi.org/10.1101/2021.08.04.21261420; this version posted August 8, 2021. The copyright holder for this preprint (which was not certified by peer review) is the author/funder, who has granted medRxiv a license to display the preprint in perpetuity.

All rights reserved. No reuse allowed without permission.

(2) Promoting physical activities. Previous studies have reported that green spaces can promote physical activities, both prior to and during the COVID-19 pandemic (Cohen et al., 2007; Lu et al., 2019; Lu, Zhao, et al., 2021). Moreover, exercising while viewing green landscape can promote synergic health outcomes, which are better than those yielded by conducting exercise while lacking a green view (Pretty et al., 2005). Numerous studies have found that access to green spaces can reduce the risk of obesity, and individuals with obesity have been found to be more vulnerable to SARS-CoV-2 infection (Jia et al., 2021; Jordan \& Adab, 2020; Sattar et al., 2020). Lastly, studies have suggested that physical activities in green spaces can enhance general health and immune function (Li et al., 2010), which may promote resistance to SARS-CoV-2 infection.

(3) Promoting mental restoration. Viewing or being in green environments can promote mental restoration by reducing stress (Hunter et al., 2019; Jiang et al., 2016; Ulrich et al., 1991), mental fatigue (Jiang et al., 2018; Kaplan, 1995; Sullivan \& Li, 2021; Yu et al., 2018), depression (Min et al., 2017), and negative moods (Jiang et al., 2020). These mental health benefits are often interlinked with physical health benefits (Berman et al., 2008; Kaplan, 1995; Zhang, Yu, Zhao, Sun, \& Vejre, 2020). Kuo (2015) argued that green spaces can promote immune function through promoting mental health, consistent with the findings of many other studies (e.g., Cohen et al., 2001; Segerstrom \& Miller, 2004). Thus, the mental health benefits of green spaces can lead to improved physiological resistance to SARS-CoV-2 infection.

(4) Promoting social cohesion and cooperation. Social health benefits are often associated with the mental and physical health benefits of green spaces (Jiang, Zhang, et al., 2015; Sullivan et al., 2014). Studies have found that living beside green spaces leads to residents having less impulsiveness and aggressiveness, greater self-discipline, and more social connections with other 
medRxiv preprint doi: https://doi.org/10.1101/2021.08.04.21261420; this version posted August 8, 2021. The copyright holder for this preprint (which was not certified by peer review) is the author/funder, who has granted medRxiv a license to display the preprint in perpetuity.

All rights reserved. No reuse allowed without permission.

residents than counterpart individuals living in barren areas (Branas et al., 2018; Kuo \& Sullivan, 2001; Lee et al., 2019). Additionally, green spaces can reduce health disparities among populations with different socioeconomic or demographic statuses (Jiang et al., 2017; Mitchell \& Popham, 2008). For example, a study found that a greater supply of green spaces was associated with a lower racial disparity in SARS-CoV-2 infection rates (Lu, Chen, et al., 2021). Social health benefits may lead to enhanced social security, cohesion, trust, and collaboration (Holtan et al., 2014; Jiang et al., 2017; Mazumdar et al., 2017), which are critical to reduce infection risk from a population behavior perspective, e.g., following orders to wear masks, maintaining physical distance, and reducing social gathering.

(5) Removing ambient pollutants. Green spaces, especially forest and trees, are critical for improving air quality. This is achieved through increased deposition rates of particulate matter on plant surfaces and/or the absorption of gaseous pollutants through leaf stomata (Janhäll, 2015; Kumar et al., 2019; Nowak et al., 2006; Nowak et al., 2014; Nowak et al., 2013; Nowak et al., 2018). These effects are not limited to forest found in urban areas, as forest in rural areas has been reported to also contribute to human health (Nowak et al., 2014). By inhibiting two major transmission routes of SARS-CoV-2, i.e., particles and aerosols, green spaces can reduce SARSCoV-2 infection risk (Bourouiba, 2020). Another reason for this effect may be related to the expression of angiotensin-converting enzyme 2 (ACE-2) in the respiratory tract, a known receptor for coronaviruses. ACE-2 is overexpressed in individuals who are exposed ambient pollutants on a daily basis, especially nitrogen dioxide $\left(\mathrm{NO}_{2}\right)$ and $2.5-\mu \mathrm{m}-$ and $10-\mu \mathrm{m}$-diameter particulate matter (PM2.5 and PM10) (Fattorini \& Regoli, 2020; Paital \& Agrawal, 2020; Zhu et al., 2020). 
medRxiv preprint doi: https://doi.org/10.1101/2021.08.04.21261420; this version posted August 8, 2021. The copyright holder for this preprint (which was not certified by peer review) is the author/funder, who has granted medRxiv a license to display the preprint in perpetuity.

All rights reserved. No reuse allowed without permission.

\subsubsection{Why forest has a stronger negative association with infection rates than other green spaces?}

In this study, a "forest" was defined as "a square $(30 \mathrm{~m} \times 30 \mathrm{~m})$ dominated by trees, generally greater than $5 \mathrm{~m}$ tall, and accounting for greater than $20 \%$ of total vegetation cover" (MRLC consortium, 2019). Thus, "forest" does not only include large forest in the rural areas, but also includes areas with small patches of trees in urban, suburban, and rural areas (Fig. 2). We propose three reasons why forest may outperform other green spaces in reducing SARS-CoV-2 infection rates.

\section{(1) Forest might be a stronger stimulus for outdoor activities compared to other green spaces.}

First, forest provides more possibilities for keeping safe physical distances than other green spaces, especially compared to other green spaces in urban areas. One study provided evidence for this argument (Lu, Zhao, et al., 2021): during the COVID-19 pandemic, more people chose to visit natural forest parks than urban parks for recreational and exercise purposes. An important explanation of this phenomenon is that compared to urban parks with limited open space, forest parks give people considerably more space to maintain a physical distance from other visitors. Second, experimental studies have found that tree canopies can create a more comfortable microclimate (Li et al., 2019; Ziter et al., 2019). Thus, forest may support outdoor activities more than other green spaces. Third, in this study, forest included lawn or grassland partially covered by tree canopies, which provide a more comfortable environment for outdoor activities than a lawn without shade or dense forest setting that has considerable shade.

(2) Forest might be more effective in boosting immune function. Forest has been reported to boost immune function in multiple ways; however, there is less evidence that other types of green 
medRxiv preprint doi: https://doi.org/10.1101/2021.08.04.21261420; this version posted August 8, 2021. The copyright holder for this preprint (which was not certified by peer review) is the author/funder, who has granted medRxiv a license to display the preprint in perpetuity.

All rights reserved. No reuse allowed without permission.

spaces can do so. Several studies have demonstrated a beneficial effect of forest therapy on human's weakened immune function (Li, 2010; Li et al., 2007; Lyu et al., 2019). These effects might be due to plant-derived phytoncides, which are antimicrobial volatile organic compounds that have been shown to reduce blood pressure, alter autonomic activity, and boost immune function by increasing the concentrations and activity of natural killer (NK) cells, among other effects (Komori et al., 1995; Li et al., 2006).

Moreover, although no study has determined whether enhanced immune function can directly reduce the risk of SARS-CoV-2 infection, studies have reported that patients with moderate-tosevere disease symptoms tend to have low concentrations of circulating NK cells, which is an indicator of impaired immune function (Jiang et al., 2020; Wang et al., 2020; Wilk et al., 2020). Additionally, reduced NK cell numbers have also been observed during the acute phase of SARSCoV-2 infection (National Research Project for SARS, 2004). This evidence implies that forest reduces the risk and severity of SARS-CoV-2 infection by boosting NK cell populations.

\section{(3) Forest has the potential to be a more mentally restorative green space than other green}

spaces. Forest has a complex three-dimensional profile, including tree trunks and canopies, and a higher level of biodiversity and greenness compared to other green spaces with relatively short and less biodiverse vegetation (Brockerhoff et al, 2017; Trochta et al, 2017). Thus, forest may have more restorative effects on mental fatigue and stress (Jiang et al., 2020). An experimental study found that streetscapes including trees more significantly reduced stress than those including grass or shrubs (Jiang, Larsen, et al., 2015; Jiang et al., 2016). Many other studies have also reported that visiting a forest park is more mentally restorative than visiting other green spaces, because of 
medRxiv preprint doi: https://doi.org/10.1101/2021.08.04.21261420; this version posted August 8, 2021. The copyright holder for this preprint (which was not certified by peer review) is the author/funder, who has granted medRxiv a license to display the preprint in perpetuity. All rights reserved. No reuse allowed without permission.

forest park's higher ecological richness and greenness (e.g., Beil \& Hanes, 2013; Wood et al., 2018).

(4) Forest may be more effective in removing ambient pollutants than other green spaces.

Many studies have suggested that forest has a greater capacity for reducing air pollution. Forest can capture particulate pollutants more efficiently than grassland and shrubs, as forest often have more complex foliage, a larger number of trees, more diverse tree heights and canopy sizes, and more diverse tree species (Beckett et al., 2000). A nationwide study of trees and forest in the contiguous United States found that trees and forest removed approximately 17.4 million tonnes of air pollution in 2010 , which was estimated to lead to 850 fewer deaths and 670,000 fewer incidents of acute respiratory symptoms (Nowak et al., 2006). One study conducted in Cambodia reported that deforestation was significantly associated with an increasing rate of acute respiratory infection in children (Pienkowski et al., 2017). Another study conducted in New York City revealed that increased tree density was significantly associated with a lower prevalence of early childhood asthma (Lovasi et al., 2008).

\subsubsection{Forest' beneficial effect across urbanicity and time}

First, the effect of forest on infection rates is most pronounced in moderately urbanized counties, although the effect remain significant across all five levels of urbanicity. As Table S8 shows, the residents of high-to-moderately high urbanized counties (urbanicity levels 1 and 2) had less forest exposure per capita compared to those in moderately urbanized counties (urbanicity level 3 ). Hence, green spaces in highly urbanized counties were shared by more people, making it more difficult for visitors to keep safe social distancing (Nobajas et al., 2020; Shoari et al., 2020). However, it is unclear why the forest-infection rate association was also weaker in rural counties 
medRxiv preprint doi: https://doi.org/10.1101/2021.08.04.21261420; this version posted August 8, 2021. The copyright holder for this preprint (which was not certified by peer review) is the author/funder, who has granted medRxiv a license to display the preprint in perpetuity.

All rights reserved. No reuse allowed without permission.

(levels 4 and 5). It may be because forest in rural counties is likely to be private properties, which are not accessible to the public. Therefore, total land coverage may not accurately reflect the total green space available to the public, and thus the population infection rate might be less influenced by forest coverage.

Second, the effect of forest on infection rate was found to increase in strength as the pandemic progressed, and similar patterns were observed for other green spaces. There are two possible reasons for this. First, in the early period, the spread of SARS-CoV-2 might have been confined to hotspots and spread mainly via intimate social gatherings or institutional activities (such as family gatherings, party of close friends, or school activities) (Leclerc et al., 2020; Thakar, 2020). Residents of these local hotspots may have had different levels of green space exposure compared to the overall county-wide levels. However, in the later period of the pandemic, SARS-CoV-2 had spread widely across the whole county and affected most residents. Thus, residents' exposure to green space may have been better reflected by county-level green space coverage in the late period, making the effect of green spaces more significant. Second, SARS-CoV-2 testing was highly inconsistent among counties and cases of infection were substantially underestimated in some areas during the early stage (Angulo et al., 2021), thus the numbers of confirmed cases of infection in the early periods are less reliable than those in the later periods.

\subsubsection{Forest within walking distance associated with reduce infection risk}

A significant finding of this study was the identification of the optimal distance from forest for infection risk reduction, by considering the spatial distribution of populations across counties. The association between population-weighted forest exposure and SARS-CoV-2 infection rates followed the pattern of diminishing marginal utility. This finding suggests that it is critical to 
medRxiv preprint doi: https://doi.org/10.1101/2021.08.04.21261420; this version posted August 8, 2021. The copyright holder for this preprint (which was not certified by peer review) is the author/funder, who has granted medRxiv a license to display the preprint in perpetuity.

All rights reserved. No reuse allowed without permission.

prioritize access to forest located within walking distance of critical masses of populations because doing so might significantly alleviate SARS-CoV-2 infection rates, in addition to providing other health benefits. The significant health benefits of nearby forest and other green spaces have been consistently reported (e.g., Corraliza \& Collado, 2011; Cox et al., 2017; Lee et al., 2019; Oh et al., 2017). The construction and conservation of nearby forest is particularly valuable when a county has limited financial and human resources, due to the potential alleviation of burdens of healthcare systems. Additionally, forest beyond walking distance also appears to alleviate infection risks, potentially by reducing ambient pollutants at a regional scale (Escobedo \& Nowak, 2009; Nowak et al., 2018).

\subsection{Originality, significance, and contributions to knowledge and practice}

This study makes original contributions to knowledge and practice that may influence future research, policymaking, planning, and design.

First, the spatiotemporal aspects of this study significantly enhance the validity and generalizability of its findings. The nationwide nature of the study provided an opportunity to investigate counties with different levels of urbanicity. The one-year span of the study also provided an opportunity to investigate the relatively complete course of a pandemic that developed from a low to high infection rate (Fig. 1). We considered the potential influence of various levels of urbanicity and time periods on the association of forest and other green spaces with reduced SARS-CoV-2 infection rates. The assumption of stationarity in relationships between environmental factors and health outcomes has been heavily criticized (Kwan, 2021). This study found that associations among green spaces and infection rates varied in significance and extent at different levels of urbanicity and over different time periods. These findings invite future studies 
that probe each outcome in greater depth so that we might better understand the associations identified here.

Second, this study identified a significant and strong negative association between green spaces and infection rates after controlling for socioeconomic and demographic, political, healthcare and testing, behavioral, and climate and environment factors. Such strong control for political and behavioral factors, such as presidential elections and the number of essential workers, has been rare in previous studies. These controls significantly increase the reliability of our findings.

Third, this study transcends a critical limitation of many ecological studies. Identifying a general positive or negative association between green spaces and health outcomes is inadequate to reveal the relationship and guide environmental interventions (Klompmaker et al., 2021). However, by determining the spatial relationship between forest and human settlements, we have greater confidence to propose an optimal buffer distance for forest that may achieve to maximal forestassociated reductions in infection rates.

\subsection{Limitations and future research opportunities}

There are four major opportunities that can be explored in future research following this study. This study reported correlational rather than casual findings. Still, the notion that exposure to green spaces, and forest in particular, lower infection rates from SARS-CoV-2 is plausible, based on the mechanisms proposed and a wealth of previous research. We suggest more experimental studies, including laboratory or natural experiments, be conducted to fully confirm these casual relationships (Jiang et al., 2021; Tyrvainen et al., 2014). 
medRxiv preprint doi: https://doi.org/10.1101/2021.08.04.21261420; this version posted August 8, 2021. The copyright holder for this preprint (which was not certified by peer review) is the author/funder, who has granted medRxiv a license to display the preprint in perpetuity.

All rights reserved. No reuse allowed without permission.

Second, we have restricted our interpretations on the significant findings to green spaces, and especially to landscapes that contain forest. We note, however, that many other factors are also significantly associated with infection rates, such as the Gini index, overcrowded housing, $\mathrm{PM}_{2.5}$ and $\mathrm{PM}_{10}$ concentrations, numbers of essential workers, modes of transport used for commuting, and public mask mandates. These factors all have significant potential to be the focal point of future studies.

Third, we did not use data collected in 2021, as vaccination programs were implemented in the majority of counties in the early months of 2021, and would have likely confound the relationship between green spaces and infection rates (BBC, 2020). Here again, we see this as an important opportunity for future research, as it is necessary to understand the extent to which varying levels vaccination rates alter the relationship between the supply of green spaces and SARS-CoV-2 infection rates and mortality rates.

Finally, although this study employed an ecological design that included a series of populationweighted assessments, the design is still vulnerable to the risk of ecological fallacy. That is, we should not draw inferences about individual levels of infection based on aggregate data gathered at the county-level. The fact that personal data related to individuals who were infected by SARSCOV-2 were not available makes overcoming this risk a challenge. Perhaps in some countries, where more data is available at the individual level, scientist can address this limitation. 
medRxiv preprint doi: https://doi.org/10.1101/2021.08.04.21261420; this version posted August 8, 2021. The copyright holder for this preprint (which was not certified by peer review) is the author/funder, who has granted medRxiv a license to display the preprint in perpetuity.

All rights reserved. No reuse allowed without permission.

\section{Conclusion}

This nationwide study is one initial study to investigate the year-long relationships between green spaces and SARS-CoV-2 infection rates at the county level. We found that forests and other green spaces have significant negative associations with the SARS-CoV-2 infection rates. Thus, preserving and developing forests and other green spaces might be important to alleviate the infection risk. Moreover, it is critical to preserve and develop forests within walking distance $(\leq$ $1.0-1.4 \mathrm{~km}$ for 12.5-17.5 mins' walking) of populations, to optimize the effects of forests on SARS-CoV-2 infection risks and maximize other potential health benefits for people. 


\section{References}

Abedi, V., Olulana, O., Avula, V., Chaudhary, D., Khan, A., Shahjouei, S., Li, J., \& Zand, R. (2020). Racial, economic, and health inequality and COVID-19 infection in the United States. Journal of Racial and Ethnic Health Disparities, 1-11.

Angulo, F. J., Finelli, L., \& Swerdlow, D. L. (2021). Estimation of US SARS-CoV-2 infections, symptomatic infections, hospitalizations, and deaths using seroprevalence surveys. JAMA Network Open, 4(1), e2033706-e2033706.

Badr, H. S., Du, H., Marshall, M., Dong, E., Squire, M. M., \& Gardner, L. M. (2020). Association between mobility patterns and COVID-19 transmission in the USA: A mathematical modelling study. The Lancet Infectious Diseases, 20(11), 1247-1254.

BBC. (2020). COVID-19: First vaccine given in US as roll-out begins. Retrieved 1 July 2021 from https://www.bbc.com/news/world-us-canada-55305720

Beckett, K. P., Freer-Smith, P. H., \& Taylor, G. (2000). Particulate pollution capture by urban trees: Effect of species and windspeed. Global Change Biology, 6(8), 995-1003.

Beil, K., \& Hanes, D. (2013). The influence of urban natural and built environments on physiological and psychological measures of stress-a pilot study. International Journal of Environmental Research and Public Health, 10(4), 1250-1267.

Berman, M. G., Jonides, J., \& Kaplan, S. (2008). The cognitive benefits of interacting with nature. Psychological Science, 19(12), 1207-1212.

Bourouiba, L. (2020). Turbulent gas clouds and respiratory pathogen emissions: Potential implications for reducing transmission of COVID-19. The Journal of the American Medical Association, 323(18), 1837-1838.

Branas, C. C., South, E., Kondo, M. C., Hohl, B. C., Bourgois, P., Wiebe, D. J., \& MacDonald, J. M. (2018). Citywide cluster randomized trial to restore blighted vacant land and its effects on violence, crime, and fear. Proceedings of the National Academy of Sciences, 115(12), 2946-2951.

Braubach, M., Egorov, A., Mudu, P., Wolf, T., Ward Thompson, C., \& Martuzzi, M. (2017). Effects of urban green space on environmental health, equity and resilience. In N. Kabisch, H. Korn, J. Stadler, \& A. Bonn (Eds.), Nature-Based Solutions to Climate Change Adaptation in Urban Areas: Linkages between Science, Policy and Practice (pp. 187-205). Springer International Publishing.

Brockerhoff, E. G., Barbaro, L., Castagneyrol, B., Forrester, D. I., Gardiner, B., González-Olabarria, J. R., ... \& Jactel, H. (2017). Forest biodiversity, ecosystem functioning and the provision of ecosystem services. Biodiversity and Conservation, 26, 3005-3035.

Carteni, A., Di Francesco, L., \& Martino, M. (2020). How mobility habits influenced the spread of the COVID-19 pandemic: Results from the Italian case study. Science of the Total Environment, 741, 140489.

Chakrabarty, R. K., Beeler, P., Liu, P., Goswami, S., Harvey, R. D., Pervez, S., van Donkelaar, A., \& Martin, R. V. (2021). Ambient PM2.5 exposure and rapid spread of COVID-19 in the United States. Science of the Total Environment, 760, 143391.

Chang, D. H. F., Jiang, B., Wong, N. H. L., Wong, J. J., Webster, C., \& Lee, T. M. C. (2021). The human posterior cingulate and the stress-response benefits of viewing green urban landscapes. NeuroImage, 226, 117555.

Chen, B., Song, Y., Jiang, T., Chen, Z., Huang, B., \& Xu, B. (2018). Real-time estimation of population exposure to PM2.5 using mobile-and station-based big data. International Journal of Environmental Research and Public Health, 15(4), 573.

Chen, B., Song, Y., Kwan, M.-P., Huang, B., \& Xu, B. (2018). How do people in different places experience different levels of air pollution? Using worldwide Chinese as a lens. Environmental Pollution, 238, 874-883. 
Chen, Y., Liu, T., \& Liu, W. (2016). Increasing the use of large-scale public open spaces: A case study of the North Central Axis Square in Shenzhen, China. Habitat International, 53, 66-77.

Clinton, J., Cohen, J., Lapinski, J., \& Trussler, M. (2021). Partisan pandemic: How partisanship and public health concerns affect individuals' social mobility during COVID-19. Science Advance, 7(2). https://doi.org/10.1126/sciadv.abd7204

Clouston, S. A., Natale, G., \& Link, B. G. (2021). Socioeconomic inequalities in the spread of coronavirus-19 in the United States: A examination of the emergence of social inequalities. Social Science \& Medicine, 268, 113554.

Cohen, D. A., McKenzie, T. L., Sehgal, A., Williamson, S., Golinelli, D., \& Lurie, N. (2007). Contribution of public parks to physical activity. American Journal of Public Health, 97(3), 509514.

Cohen, S., Miller, G. E., \& Rabin, B. S. (2001). Psychological stress and antibody response to immunization: A critical review of the human literature. Psychosomatic Medicine, 63(1), 7-18.

Coley, R. Kuo, F. E., \& Sullivan, W. C. (1997). Where does community grow? The social context created by nature in urban public housing. Environment and Behavior, 29(4), 468-494.

Corraliza, J. A., \& Collado, S. (2011). Nearby nature as a moderator of stress during childhood. Psicothema, 23(2), 221-226.

Coulston, J. W., Jacobs, D. M., King, C. R., \& Elmore, I. C. (2013). The influence of multi-season imagery on models of canopy cover. Photogrammetric Engineering \& Remote Sensing, 79(5), 469-477.

Coulston, J. W., Moisen, G. G., Wilson, B. T., Finco, M. V., Cohen, W. B., \& Brewer, C. K. (2012). Modeling percent tree canopy cover: A pilot study. Photogrammetric Engineering \& Remote Sensing, 78(7), 715-727.

Cox, D. T. C., Shanahan, D. F., Hudson, H. L., Plummer, K. E., Siriwardena, G. M., Fuller, R. A., Anderson, K., Hancock, S., \& Gaston, K. J. (2017). Doses of neighborhood nature: The benefits for mental health of living with nature. BioScience, 67(2), 147-155.

Donovan, G. H., Michael, Y. L., Butry, D. T., Sullivan, A. D., \& Chase, J. M. (2011). Urban trees and the risk of poor birth outcomes. Health and Place, 17(1), 390-393.

Escobedo, F. J., \& Nowak, D. J. (2009). Spatial heterogeneity and air pollution removal by an urban forest. Landscape and Urban Planning, 90(3-4), 102-110.

Fattorini, D., \& Regoli, F. (2020). Role of the chronic air pollution levels in the COVID-19 outbreak risk in Italy. Environmental Pollution, 264, 114732.

Figueroa, J. F., Wadhera, R. K., Mehtsun, W. T., Riley, K., Phelan, J., \& Jha, A. K. (2021, March). Association of race, ethnicity, and community-level factors with COVID-19 cases and deaths across US counties. Healthcare, 9(1), 100495.

Geng, D., Innes, J., Wu, W., \& Wang, G. (2021). Impacts of COVID-19 pandemic on urban park visitation: A global analysis. Journal of Forestry Research, 32(2), 553-567.

Grahn, P., \& Stigsdotter, U. A. (2003). Landscape planning and stress. Urban Forestry \& Urban Greening, 2(1), 1-18.

Helbich, M., O'Connor, R. C., Nieuwenhuijsen, M., \& Hagedoorn, P. (2020). Greenery exposure and suicide mortality later in life: A longitudinal register-based case-control study. Environment International, 143, 105982.

Holman, E. A., Thompson, R. R., Garfin, D. R., \& Silver, R. C. (2020). The unfolding COVID-19 pandemic: A probability-based, nationally representative study of mental health in the United States. Science Advance, 6(42).

Holtan, M. T., Dieterlen, S. L., \& Sullivan, W. C. (2014). Social life under cover: Tree canopy and scoia capital in Baltimore, Maryland. Environment and Behavior, 46(6), 1-24.

Huang, Q., Jackson, S., Derakhshan, S., Lee, L., Pham, E., Jackson, A., \& Cutter, S. L. (2021). Urbanrural differences in COVID-19 exposures and outcomes in the South: A preliminary analysis of South Carolina. PloS One, 16(2), e0246548. 
medRxiv preprint doi: https://doi.org/10.1101/2021.08.04.21261420; this version posted August 8, 2021. The copyright holder for this preprint

(which was not certified by peer review) is the author/funder, who has granted medRxiv a license to display the preprint in perpetuity.

All rights reserved. No reuse allowed without permission.

Hunter, M. R., Gillespie, B. W., \& Chen, S. Y.-P. (2019). Urban nature experiences reduce stress in the context of daily life based on salivary biomarkers. Frontiers in Psychology, 10(722).

Janhäll, S. (2015). Review on urban vegetation and particle air pollution: Deposition and dispersion. Atmospheric Environment, 105, 130-137.

Jia, P., Cao, X., Yang, H., Dai, S., He, P., Huang, G., Wu, T., \& Wang, Y. (2021). Green space access in the neighbourhood and childhood obesity. Obesity Reviews, 22(S1), e13100.

Jiang, B., Chang, C.-Y., \& Sullivan, W. C. (2014). A dose of nature: Tree cover, stress reduction, and gender differences. Landscape and Urban Planning, 132(0), 26-36.

Jiang, B., He, J., Chen, J., Larsen, L., \& Wang, H. (2020). Perceived green at speed: A simulated driving experiment raises new questions for Attention Restoration Theory and Stress Reduction Theory. Environment and Behavior, 0013916520947111.

Jiang, B., Larsen, L., Deal, B., \& Sullivan, W. C. (2015). A dose-response curve describing the relationship between tree cover density and landscape preference. Landscape and Urban Planning, 139(0), 16-25.

Jiang, B., Li, D., Larsen, L., \& Sullivan, W. C. (2016). A dose-response curve describing the relationship between urban tree cover density and self-reported stress recovery. Environment and Behavior, 48(4), 607-629.

Jiang, B., Mak, C. N. S., Larsen, L., \& Zhong, H. (2017). Minimizing the gender difference in perceived safety: Comparing the effects of urban back alley interventions. Journal of Environmental Psychology, 51, 117-131.

Jiang, B., Schmillen, R., \& Sullivan, W. C. (2018). How to waste a break: Using portable electronic devices substantially counteracts attention enhancement effects of green spaces. Environment and Behavior, 0013916518788603.

Jiang, B., Shen, K., Sullivan, W. C., Yang, Y., Liu, X., \& Lu, Y. (2021). A natural experiment reveals impacts of built environment on suicide rate: Developing an environmental theory of suicide. Science of the Total Environment, 776, 145750.

Jiang, B., Zhang, T., \& Sullivan, W. C. (2015). Healthy cities: Mechanisms and research questions regarding the impacts of urban green landscapes on public health and well-being. Landscape Architecture Frontier, 3(1), 24-35.

Jiang, X., Larsen, L., \& Sullivan, W. (2020). Connections between daily greenness exposure and health outcomes. International Journal of Environmental Research and Public Health, 17(11), 3965.

Jiang, Y., Wei, X., Guan, J., Qin, S., Wang, Z., Lu, H., Qian, J., Wu, L., Chen, Y., \& Chen, Y. (2020). COVID-19 pneumonia: CD8+ T and NK cells are decreased in number but compensatory increased in cytotoxic potential. Clinical Immunology, 218, 108516.

Jordan, R. E., \& Adab, P. (2020). Who is most likely to be infected with SARS-CoV-2? The Lancet Infectious Diseases, 20(9), 995-996.

Kaplan, S. (1995). The restorative benefits of nature - toward an integrative framework. Journal of Environmental Psychology, 15(3), 169-182.

Karaye, I. M., \& Horney, J. A. (2020). The impact of social vulnerability on COVID-19 in the US: An analysis of spatially varying relationships. American Journal of Preventive Medicine, 59(3), 317325.

Klompas, M., Baker, M. A., \& Rhee, C. (2020). Airborne transmission of SARS-CoV-2: Theoretical considerations and available evidence. JAMA, 324(5), 441-442.

Klompmaker, J. O., Hart, J. E., Holland, I., Sabath, M. B., Wu, X., Laden, F., Dominici, F., \& James, P. (2021). County-level exposures to greenness and associations with COVID-19 incidence and mortality in the United States. Environmental Research, 199, 111331.

Komori, T., Fujiwara, R., Tanida, M., Nomura, J., \& Yokoyama, M. M. (1995). Effects of citrus fragrance on immune function and depressive states. Neuroimmunomodulation, 2(3), 174-180.

Kumar, P., Druckman, A., Gallagher, J., Gatersleben, B., Allison, S., Eisenman, T. S., Hoang, U., Hama, S., Tiwari, A., Sharma, A., Abhijith, K. V., Adlakha, D., McNabola, A., Astell-Burt, T., Feng, X., 
medRxiv preprint doi: https://doi.org/10.1101/2021.08.04.21261420; this version posted August 8, 2021. The copyright holder for this preprint

(which was not certified by peer review) is the author/funder, who has granted medRxiv a license to display the preprint in perpetuity.

All rights reserved. No reuse allowed without permission.

Skeldon, A. C., de Lusignan, S., \& Morawska, L. (2019). The nexus between air pollution, green infrastructure and human health. Environment International, 133, 105181.

Kuo, F., \& Sullivan, W. (2001). Environment and crime in the inner city: Does vegetation reduce crime? Environment and Behavior, 33(3), 343-367.

Kuo, F. E., \& Sullivan, W. C. (2001). Aggression and violence in the inner city: Effects of environment via mental fatigue. Environment and Behavior, 33(4), 543-571.

Kuo, M. (2015). How might contact with nature promote human health? Promising mechanisms and a possible central pathway. Frontiers in Psychology, 6(1093).

Kwan, M.-P. (2021). The stationarity bias in research on the environmental determinants of health. Health \& Place, $70,102609$.

Leclerc, Q. J., Fuller, N. M., Knight, L. E., CMMID COVID-19 Working Group, Funk, S., Knight, G. M. (2020). What settings have been linked to SARS-CoV-2 transmission clusters? Wellcome Open Research, 5, 83.

Lee, M., Kim, S., \& Ha, M. (2019). Community greenness and neurobehavioral health in children and adolescents. Science of the Total Environment, 672, 381-388.

Li, J., Liu, J., Srebric, J., Hu, Y., Liu, M., Su, L., \& Wang, S. (2019). The effect of tree-planting patterns on the Microclimate within a Courtyard. Sustainability, 11(6).

Li, Q. (2010). Effect of forest bathing trips on human immune function. Environmental Health and Preventive Medicine, 15(1), 9-17.

Li, Q., Kobayashi, M., Inagaki, H., Hirata, Y., Li, Y. J., Hirata, K., Shimizu, T., Suzuki, H., Katsumata, M., Wakayama, Y., Kawada, T., Ohira, T., Matsui, N., \& Kagawa, T. (2010). A day trip to a forest park increases human natural killer activity and the expression of anti-cancer proteins in male subjects. Journal of Biological Regulators and Homeostatic Agents, 24(2), 157-165.

Li, Q., Morimoto, K., Nakadai, A., Inagaki, H., Katsumata, M., Shimizu, T., Hirata, Y., Hirata, K., Suzuki, H., \& Miyazaki, Y. (2007). Forest bathing enhances human natural killer activity and expression of anti-cancer proteins. International Journal of Immunopathology and Pharmacology, 20(2_suppl), 3-8.

Li, Q., Nakadai, A., Matsushima, H., Miyazaki, Y., Krensky, A. M., Kawada, T., \& Morimoto, K. (2006). Phytoncides (Wood Essential Oils) induce human natural killer cell activity. Immunopharmacology and Immunotoxicology, 28(2), 319-333.

Liu, K., Siu, K. W. M., Gong, X. Y., Gao, Y., \& Lu, D. (2016). Where do networks really work? The effects of the Shenzhen greenway network on supporting physical activities. Landscape and Urban Planning, 152, 49-58.

Lovasi, G. S., Quinn, J. W., Neckerman, K. M., Perzanowski, M. S., \& Rundle, A. (2008). Children living in areas with more street trees have lower prevalence of asthma. Journal of Epidemiology and Community Health, 62(7), 647-649.

Lu, Y. (2018). Using Google Street View to investigate the association between street greenery and physical activity. Landscape and Urban Planning, 191, 103435.

Lu, Y., Chen, L., Liu, X., Yang, Y., Sullivan, W. C., Xu, W., Webster, C., \& Jiang, B. (2021). Green spaces mitigate racial disparity of health: A higher ratio of green spaces indicates a lower racial disparity in SARS-CoV-2 infection rates in the USA. Environment International, 152, 106465.

Lu, Y., Yang, Y., Sun, G., \& Gou, Z. (2019). Associations between overhead-view and eye-level urban greenness and cycling behaviors. Cities, 88, 10-18.

Lu, Y., Zhao, J., Wu, X., \& Lo, S. M. (2021). Escaping to nature during a pandemic: A natural experiment in Asian cities during the COVID-19 pandemic with big social media data. Science of the Total Environment, 777, 146092.

Lyu, B., Zeng, C., Xie, S., Li, D., Lin, W., Li, N., Jiang, M., Liu, S., \& Chen, Q. (2019). Benefits of a three-day bamboo forest therapy session on the psychophysiology and immune system responses of male college students. International Journal of Environmental Research and Public Health, $16(24), 4991$. 
medRxiv preprint doi: https://doi.org/10.1101/2021.08.04.21261420; this version posted August 8, 2021. The copyright holder for this preprint

(which was not certified by peer review) is the author/funder, who has granted medRxiv a license to display the preprint in perpetuity.

All rights reserved. No reuse allowed without permission.

Mazumdar, S., Learnihan, V., Cochrane, T., \& Davey, R. (2017). The built environment and social capital: A systematic review. Environment and Behavior, 50(2), 119-158.

McGrail, D. J., Dai, J., McAndrews, K. M., \& Kalluri, R. (2020). Enacting national social distancing policies corresponds with dramatic reduction in COVID19 infection rates. PloS One, 15(7), e0236619.

Melis, G., Gelormino, E., Marra, G., Ferracin, E., \& Costa, G. (2015). The effects of the urban built environment on mental health: A cohort study in a Large Northern Italian City. International Journal of Environmental Research and Public Health, 12(11).

Mena, G. E., Martinez, P. P., Mahmud, A. S., Marquet, P. A., Buckee, C. O., \& Santillana, M. (2021). Socioeconomic status determines COVID-19 incidence and related mortality in Santiago, Chile. Science, 372(6545).

Min, K.-b., Kim, H.-J., Kim, H.-J., \& Min, J.-y. (2017). Parks and green areas and the risk for depression and suicidal indicators. International Journal of Public Health, 62(6), 647-656.

Mitchell, R., \& Popham, F. (2008). Effect of exposure to natural environment on health inequalities: An observational population study. Lancet, 372(9650), 1655-1660.

MRLC consortium (2019). National Land Cover Database 2019 (NLCD2019) Legend. Retrieved 1 July 2021 from https://www.mrlc.gov/data/legends/national-land-cover-database-2016-nlcd2016legend.

Muller, N. F., Wagner, C., Frazar, C. D., Roychoudhury, P., Lee, J., Moncla, L. H., Pelle, B., Richardson, M., Ryke, E., Xie, H., Shrestha, L., Addetia, A., Rachleff, V. M., Lieberman, N. A. P., Huang, M. L., Gautom, R., Melly, G., Hiatt, B., Dykema, P.,(...) Bedford, T. (2021). Viral genomes reveal patterns of the SARS-CoV-2 outbreak in Washington State. Science Translational Medicine, 13(595). https://doi.org/10.1126/scitranslmed.abf0202

National Research Project for SARS, B. G. (2004). The involvement of natural killer cells in the pathogenesis of severe acute respiratory syndrome. American Journal of Clinical Pathology, 121(4), 507-511.

NCHS. (2017). NCHS Urban-Rural Classification Scheme for Counties. Retrieved 1 July 2021 from https://www.cdc.gov/nchs/data_access/urban_rural.htm

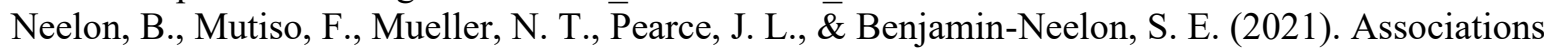 between governor political affiliation and COVID-19 cases, deaths, and testing in the US. American Journal of Preventive Medicine, 61(1), 115-119.

Nobajas, A., i Casas, J. G., i Agusti, D. P., \& Peacock, A. J. (2020). Lack of sufficient public space can limit the effectiveness of COVID-19's social distancing measures. medRxiv. Retrieved 30 June 2021 from https://www.medrxiv.org/content/10.1101/2020.06.07.20124982v2.

Nowak, D. J., Crane, D. E., \& Stevens, J. C. (2006). Air pollution removal by urban trees and shrubs in the United States. Urban Forestry \& Urban Greening, 4(3-4), 115-123.

Nowak, D. J., Hirabayashi, S., Bodine, A., \& Greenfield, E. (2014). Tree and forest effects on air quality and human health in the United States. Environmental Pollution, 193, 119-129.

Nowak, D. J., Hirabayashi, S., Bodine, A., \& Hoehn, R. (2013). Modeled PM2.5 removal by trees in ten U.S. cities and associated health effects. Environmental Pollution, 178, 395-402.

Nowak, D. J., Hirabayashi, S., Doyle, M., McGovern, M., \& Pasher, J. (2018). Air pollution removal by urban forests in Canada and its effect on air quality and human health. Urban Forestry \& Urban Greening, 29, 40-48.

O'Brien, R. M. (2007). A caution regarding rules of thumb for variance inflation factors. Quality \& Quantity, 41(5), 673-690.

Oh, B., Lee, K. J., Zaslawski, C., Yeung, A., Rosenthal, D., Larkey, L., \& Back, M. (2017). Health and well-being benefits of spending time in forests: Systematic review. Environmental Health and Preventive Medicine, 22(1), 71-71.

Ouyang, W., Morakinyo, T. E., Ren, C., \& Ng, E. (2020). The cooling efficiency of variable greenery coverage ratios in different urban densities: A study in a subtropical climate. Building and Environment, 174, 106772. 
medRxiv preprint doi: https://doi.org/10.1101/2021.08.04.21261420; this version posted August 8, 2021. The copyright holder for this preprint

(which was not certified by peer review) is the author/funder, who has granted medRxiv a license to display the preprint in perpetuity.

All rights reserved. No reuse allowed without permission.

Paital, B., \& Agrawal, P. K. (2020). Air pollution by $\mathrm{NO}_{2}$ and $\mathrm{PM}_{2.5}$ explains COVID-19 infection severity by overexpression of angiotensin-converting enzyme 2 in respiratory cells: A review. Environmental Chemistry Letters, 1-18.

Parsons, R., Tassinary, L. G., Ulrich, R. S., Hebl, M. R., \& Grossman-Alexander, M. (1998). The view from the road: Implications for stress recovery and immunization. Journal of Environmental Psychology, 18(2), 113-140.

Pienkowski, T., Dickens, B. L., Sun, H., \& Carrasco, L. R. (2017). Empirical evidence of the public health benefits of tropical forest conservation in Cambodia: A generalised linear mixed-effects model analysis. The Lancet Planetary Health, 1(5), e180-e187.

Power, M. C., Kioumourtzoglou, M.-A., Hart, J. E., Okereke, O. I., Laden, F., \& Weisskopf, M. G. (2015). The relation between past exposure to fine particulate air pollution and prevalent anxiety: Observational cohort study. British Medical Journal, 350. https://doi.org/10.1136/bmj.h1111

Pretty, J., Peacock, J., Sellens, M., \& Griffin, M. (2005). The mental and physical health outcomes of green exercise. International Journal of Environmental Health Research, 15(5), 319-337.

Pro, G., Hubach, R., Wheeler, D., Camplain, R., Haberstroh, S., Giano, Z., Camplain, C., \& Baldwin, J. A. (2020). Differences in US COVID-19 case rates and case fatality rates across the urban-rural continuum. Rural and Remote Health, 20(3), 6074.

R Core Team. (2020). $R$ : A language and environment for statistical computing. Vienna, Austria: $R$ Foundation for Statistical Computing; 2020. Retrieved 1 July 2021 from http://www.Rproject.org.

Sattar, N., McInnes, I. B., \& McMurray, J. J. V. (2020). Obesity is a risk factor for severe COVID-19 infection. Circulation, 142(1), 4-6.

Schipperijn, J., Bentsen, P., Troelsen, J., Toftager, M., \& Stigsdotter, U. K. (2013). Associations between physical activity and characteristics of urban green space. Urban Forestry \& Urban Greening, 12(1), 109-116.

Segerstrom, S. C., \& Miller, G. E. (2004). Psychological stress and the human immune system: A metaanalytic study of 30 years of inquiry. Psychological Bulletin, 130(4), 601-630.

Shoari, N., Ezzati, M., Baumgartner, J., Malacarne, D., \& Fecht, D. (2020). Accessibility and allocation of public parks and gardens in England and Wales: A COVID-19 social distancing perspective. PloS One, 15(10), e0241102.

Sorichetta, A., Hornby, G. M., Stevens, F. R., Gaughan, A. E., Linard, C., \& Tatem, A. J. (2015). Highresolution gridded population datasets for Latin America and the Caribbean in 2010, 2015, and 2020. Scientific Data, 2(1), 1-12.

Sullivan, W. C., \& Bartlett, P. F. (2005). Nature at home: An evolutionary perspective. In Peggy F. Bartlett (Eds), Urban Place: Reconnecting with the Natural World (pp. 237-252). Cambridge: MIT Press, 2005.

Sullivan, W. C., Frumkin, H., Jackson, R. J., \& Chang, C.-Y. (2014). Gaia meets Asclepius: Creating healthy places. Landscape and Urban Planning, 127, 182-184.

Sullivan, W. C., Kuo, F. E., \& DePooter, S. F. (2004). The fruit of urban nature: Vital neighborhood spaces. Environment and Behavior, 36(5), 678-700.

Sullivan, W. C., \& Li, D. (2021). Nature and attention. In A. R. Schutte, J. Torquati, \& J. R. Stevens (Eds.), Nature and psychology: Biological, cognitive, developmental, and social pathways to well-being. Springer Nature.

Thakar, V. (2020). Unfolding events in space and time: Geospatial insights into COVID-19 diffusion in Washington State during the initial stage of the outbreak. ISPRS International Journal of GeoInformation, 9(6), 382.

The New York Times. (2021). Coronavirus in the U.S.: Latest Map and Case Count. Retrieved 13 July 2021 from https://www.nytimes.com/interactive/2021/us/covid-cases.html

Tirachini, A., \& Cats, O. (2020). COVID-19 and public transportation: Current assessment, prospects, and research needs. Journal of Public Transportation, 22(1), 1-21. 
medRxiv preprint doi: https://doi.org/10.1101/2021.08.04.21261420; this version posted August 8, 2021. The copyright holder for this preprint

(which was not certified by peer review) is the author/funder, who has granted medRxiv a license to display the preprint in perpetuity.

All rights reserved. No reuse allowed without permission.

Townsend, M. J., Kyle, T. K., \& Stanford, F. C. (2020). Outcomes of COVID-19: Disparities in obesity and by ethnicity/race. International Journal of Obesity, 44, 1807-1809.

Trochta, J., Krůček, M., Vrška, T., \& Král, K. (2017). 3D Forest: An application for descriptions of threedimensional forest structures using terrestrial LiDAR. PloS One, 12(5), e0176871.

Tyrvainen, L., Ojala, A., Korpela, K., Lanki, T., Tsunetsugu, Y., \& Kagawa, T. (2014). The influence of urban green environments on stress relief measures: A field experiment. Journal of Environmental Psychology, 38, 1-9.

Ulrich, R. S., Simons, R. F., Losito, B. D., Fiorito, E., Miles, M. A., \& Zelson, M. (1991). Stress recovery during exposure to natural and urban environments. Journal of Environmental Psychology, 11(3), 201-230.

USAFACTS. (2021). About USAFacts. Retrieved 20 July 2021 from https://usafacts.org/about-usafacts/.

Esri. (2021). USA Parks. Retrieved 20 July 2021 from https://www.arcgis.com/home/item.html?id=578968f975774d3fab79fe56c8c90941.

Walker, P. G. T., Whittaker, C., Watson, O. J., Baguelin, M., Winskill, P., Hamlet, A., Djafaara, B. A., Cucunuba, Z., Olivera Mesa, D., Green, W., Thompson, H., Nayagam, S., Ainslie, K. E. C., Bhatia, S., Bhatt, S., Boonyasiri, A., Boyd, O., Brazeau, N. F., Cattarino, L., (...) Ghani, A. C. (2020). The impact of COVID-19 and strategies for mitigation and suppression in low- and middle-income countries. Science, 369(6502), 413-422.

Wang, F., Nie, J., Wang, H., Zhao, Q., Xiong, Y., Deng, L., Song, S., Ma, Z., Mo, P., \& Zhang, Y. (2020). Characteristics of peripheral lymphocyte subset alteration in COVID-19 pneumonia. The Journal of infectious diseases, 221(11), 1762-1769.

Wang, J., Tang, K., Feng, K., Li, X., Lv, W., Chen, K., \& Wang, F. (2020). High temperature and high humidity reduce the transmission of COVID-19. arXiv preprint arXiv:2003.05003. Retrieved 20 July 2021 from https://arxiv.org/abs/2003.05003

Wilk, A. J., Rustagi, A., Zhao, N. Q., Roque, J., Martínez-Colón, G. J., McKechnie, J. L., Ivison, G. T., Ranganath, T., Vergara, R., \& Hollis, T. (2020). A single-cell atlas of the peripheral immune response in patients with severe COVID-19. Nature Medicine, 26(7), 1070-1076.

Wood, E., Harsant, A., Dallimer, M., Cronin de Chavez, A., McEachan, R. R. C., \& Hassall, C. (2018). Not all green space is created equal: Biodiversity predicts psychological restorative benefits from urban green space. Frontiers in Psychology, 9(2320). https://doi.org/10.3389/fpsyg.2018.02320

World Health Organization. (2021). Coronavirus disease (COVID-19) weekly epidemiological update and weekly operational update. Retrieved 20 July 2021 from https://www.who.int/emergencies/diseases/novel-coronavirus-2019/situation-reports

Wu, S. L., Mertens, A. N., Crider, Y. S., Nguyen, A., Pokpongkiat, N. N., Djajadi, S., Seth, A., Hsiang, M. S., Colford, J. M., \& Reingold, A. (2020). Substantial underestimation of SARS-CoV-2 infection in the United States. Nature Communications, 11(1), 1-10.

Yang, Y., \& Diez-Roux, A. V. (2012). Walking distance by trip purpose and population subgroups. American Journal of Preventive Medicine, 43(1), 11-19.

Yu, C.-P., Lee, H.-Y., \& Luo, X.-Y. (2018). The effect of virtual reality forest and urban environments on physiological and psychological responses. Urban Forestry \& Urban Greening, 35, 106-114.

Zhang, J., Yu, Z., Zhao, B., Sun, R., \& Vejre, H. (2020). Links between green space and public health: A bibliometric review of global research trends and future prospects from 1901 to 2019.

Environmental Research Letters, 15(6), 063001.

Zhang, R., Li, Y., Zhang, A. L., Wang, Y., \& Molina, M. J. (2020). Identifying airborne transmission as the dominant route for the spread of COVID-19. Proceedings of the National Academy of Sciences, 117(26), 14857-14863.

Zhu, Y., Xie, J., Huang, F., \& Cao, L. (2020). Association between short-term exposure to air pollution and COVID-19 infection: Evidence from China. Science of the Total Environment, 727, 138704.

Ziter, C. D., Pedersen, E. J., Kucharik, C. J., \& Turner, M. G. (2019). Scale-dependent interactions between tree canopy cover and impervious surfaces reduce daytime urban heat during summer. Proceedings of the National Academy of Sciences, 116(15), 7575-7580. 
medRxiv preprint doi: https://doi.org/10.1101/2021.08.04.21261420; this version posted August 8, 2021. The copyright holder for this preprint (which was not certified by peer review) is the author/funder, who has granted medRxiv a license to display the preprint in perpetuity.

All rights reserved. No reuse allowed without permission.

\section{Contributions}

BJ and YL proposed the research idea. YL and BJ conducted research design and guided the data collection and data analysis. BJ, YL, YWY, and CL conducted writing of manuscript. YWY, LC, XYW, XML, and JJW conducted the data collection and data treatment. LC and YWY conducted the data analysis with support from XYW and XML. BC and CW guided a key part of research design and data analysis. WCS reviewed and revised key parts of the manuscript. XML and XYW conducted the graphic design. 